\title{
DE AFSLUITING EN DROOGMAKING VAN DE ZUIDERZEE VAN EEN ECONOMISCH STANDPUNT BESCHOUWD.
}

Behoort de Luiderzee te worden drooggemaakt?

Land aan het water te ontwoekeren was ten allen tijde in Nederland een bij uitstek nationaal bedrijf. Agrum agris copulantes vix mari concedunt at terminum suum faciat, wordt reeds in een der oudste kronieken van de bewoners dezer landen gezegd. Genoodzaakt den laag gelegen grond tegen het water te beveiligen, was men er uit den aard der zaak reeds vroegtijdig op bedacht ook aanvallenderwijs optetreden: allereerst om den waterwolf des te krachtiger te kunnen bestrijden, de afslijting van het aan het water grenzende land en overstrooming bij hoogen vloed te voorkomen, en dan om nieuwe akkers aan te winneu. "Van water land te maken tot bewoning, voedsel en dienst der menschen, is, zooals in de octrooien tot bedijking door de Staten van Holland en West-Friesland verleend herhaaldelijk wordt verklaard, ten allen tijde als een goed werk beschouwd."

Wat in den loop der tijden, vaak in benarde dagen, met gebrekkige hulpmiddelen en in weerwil van velerlei teleurstelling door onze voorvaderen in dit opzicht is tot stand gebracht, getuigt van een ondernemingsgeest en volharding, die door het tegenwoordig geslacht hoogstens kan worden geëvenaard, doch niet overtroffen. Gedurende den tachtigjarigen oorlog werden alleen in Holland benoorden het IJ niet minder dan 69 meeren en plassen door particuliere krachten drooggelegd, en ook daarna heeft men èn in Holland èn in de noordelijke provincien allerminst gerust. Tot in onze dagen is bijna onafgebroken op den ingeslagen weg voortgeschreden, zij het ook in deze eeuw dikwerf met behulp vau den Staat of, zooals

ECoN. 1897. 
bij het Haarlemmermeer, door dezen zelven. Het kon nauwelijks uitblijven, dat ten slotte het denkbeeld opkwam om ook den grootsten waterplas, de Zuiderzee, droog te leggen, en alleszins verklaarbaar is het dat dit plan, al werd het, toen bet een vijftigtal jaren geleden voor het eerst werd geopperd, met schouderophalen begroet, herhaaldelijk weder te berde kwam, en door onze eerste waterbouwkundigen aan een ernstig en nauwgezet onderzoek werd onderworpen. Aan de Zuiderzee het land te ontnemen, waarvan zij zich vóór eeuwen met geweld heeft meester gemaakt, ligt als het ware in de lijn onzer historie.

Aantrekkelijk is het denkbeeld in hooge mate. Nederland zou op vreedzame wijze eene twaalfde provincie verwerven en eene provincie, die in vruchtbaarheid van den bodem voor geen der oude gewesten zou onderdoen. Eene oppervlakte van 212.000 hectaren zou worden aangewonnen. Zeeland is slechts 175.000 hectaren groot; Utrecht beslaat niet meer dan 138.000 hectaren. En van die 212000 H.A. zouden 194.000 H.A. uit vruchtbaar land bestaan, eene uitgestrektheid aan voor cultuur geschikte gronden van ongeveer denzelfden omvang als Groningen en Orerijssel bezitten, en vrij wat grooter dan in Drenthe of Limburg wordt aangetroffen.

De nieuwe provincie zou voor de Nederlandsche volkswelvaart, vooral mettertijd, eene winst van buitengewone beteekenis zijn. De bebouwing van de Zuiderzeevelden zal aan duizenden, arbeiders en ondernemers, een middel van bestaan geven, de opbrengst van den nationalen bodem belangrijk doen stijgen en nieuwe rraag doen ontstaan naar allerlei diensten en roortbrengselen, die aan handel en nijverheid ten goede zal komen. Eene rijke bron van welvaart zal worden geopend, waarvan de weerga in de gesohiedenis onzer droogmakingen niet is te vinden. De Haarlemmermeer, de grootste der drooggemaakte polders, heeft nog niet éen elfde van de oppervlakte, die de Zuiderzeepolders zullen bestaan. De meeren en plassen van Holland's Noorderkwartier, in de $16^{\mathrm{e}}$ en $17^{\mathrm{e}}$ eeuw drooggemaakt, daaronder begrepen de Zijpe, de Beemster, de Purmer, de Heer Hugowaard, de Schermer, zijn allen te zamen niet meer dan ruim 40.000 bunders groot. De van 1440- 
1855 in Noord en Zuid-Holland drooggemaakte polders beslaan te zamen slechts 107.000 bunders. ${ }^{1}$ )

En behalve dat de exploitatie van de gronden voor de volkswelvaart veel belooft, ${ }^{2}$ ) is de droogmaking een werk van buitengewonen omvang, dat aan vele handen arbeid zal geven. Al zal het leggen der dijken en het uitpompen van het water met behulp van werktuigen van de nieuwste vinding geschieden en betrekkelijk geen groot aantal arbeiders eischen, de werktuigen zullen vervaardigd moeten worden, en aanzienlijke hoeveelheden rijshout, steenen en andere materialen zullen noodig zijn, die voortgebracht en aangevoerd zullen moeten worden. En is een polder eenmaal drooggelegd, dan zal voor het verkavelen en zwart maken der velden, het maken van wegen, vaarten en bruggen, het bouwen van woningen en schuren, kerken en scholen en andere openbare gebouwen, in één woord voor al wat noodig is om de onafzienbare vlakte voor haar doel bruikbaar en voor den mensch bewoonbaar te doen zijn eene buitengewone vraag naar vele goederen en naar arbeid van allerlei soort ontstaan.

Voor menigeen ligt reeds in dit laatste geen geringe reden tot aanprijzing van de onderneming. Wat in de aanvragen

1) Een staat dezer polders werd samengesteld door Dr. C. H. van der Boon Mesch: De droogmaking van het Haarlemmermeer. Tijdschrift ter bevordering van nijverheid XVIII pag. 337.

$\left.{ }^{2}\right)$ In een in 1848 verschenen werkje: $\mathrm{De}$ ind jijking en droogmaking van de $\mathrm{Z}$ uiderzee en het IJ met kanalen van af den IJssel bij Arnhem, langs Amsterdam tot in de Noordzee, voorgesteld en angeprezen alseen krachtig middel tot verheffing van handel, scheepvaart en landbouw in Nederland wordt ook nog als een der voordeelen van de droogmaking genoemd, dat al de stadsgrachten van Amsterdam alsdan drinkbaar water zouden opleveren. «De gelden, welke men ter verwezenlijking van de plannen tot het aanleggen van waterleidingen wilde bezigen, waren nuttiger aan de droogmaking der Zuiderzee besteed.»

Bij het in Amsterdam heerschend watergebrek zou de droogmaking, ware deze voorstelling juist, een heerlijke uitkomst voor het stedelijk bestuar zij̄n. 
om octrooi tot bedijking, die in de zeventiende eeuw tot de Staten van Holland en West-Friesland werden gericht, steeds werd herinnerd: dat voor het gemeene land van Hollandt daaraan in alle manieren veel gelegen is, dat er groote werken bij de hand genomen worden, waardoor vele lieden, zoo met arbeiden en toemaken en bouwen in het land kunnen worden gehouden" - wordt thans op allerlei wijs herhaald. De nationale Zuiderzee Bond, door wakkere industrieelen opgericht om de Zuiderzee-Vereeniging in haar propaganda ter zijde te staan, schrijft in een kort woord aan het Nederlandsche Volk: Indien de droogmaking ter hand wordt genomen, zal gedurende een reeks van jaren in ons land de productie der steenbakkerijen, de rijshontteelt, de binnenlandsche schippersvloot, de Rijnvaarl, de industrie een ruim on gezond débouché hebben, zonder dat het na afloop plotseling an een eind komt, terwijl gedurende dien tijd de zekerheid oun tot behoorlijken prijs ruimen afzet voor de nationale producten te vinden door het geheele land, ook in den winter, anleiding zal geven om land en bosch beter te doen bewerken en alle bedrijven, die ook slechts zijdelings samenhaugen met scheepvaart en industrie gedurende dienzelfden tijd tot weerdere inspanning en dus tot meerdere welvaart zullen geprikkeld worden." De droogmaking zou in dit opzicht, vooral in den tegenwoordigen tijd, velen zeer gelegen koinen. $\operatorname{Er}$ is, naar aannemers beweren, behoefte aan werk. In de laatste 30 jaren zijn omvangrijke werken van openbaar nut tot stand gebracht. Alle plaatsen van beteekenis zijn door een uitgebreid spoorwegnet onderling verbonden; voor het vervoer te water zijn nieuwe wegen gemaakt; en onze groote steden zijn om te voldoen aan den aanwas van bevolking belangrijk uitgelegd en voorzien van allerlei inrichtingen, die de moderne tijd eischt. Op deze periode van buitengewone bedrijvigheid is een tijdperk van betrekkelijke kalmte gevolgd. Nieuwe werken van beteekenis zijn niet ondernomen, en al dreigen dientengevolge nu niet - zooals een geestdriftig voorstander van de droogmaking, de Delftsche hoogleeraar Telders in eene door de Zuiderzee-Vereeniging uitgegeven rede oordeelde - "duizenden in den lande, industrieelen en fabrikanten, ingenieurs en opzichters, aannemers en werk- 
bazen, ambachtslieden en rijswerkers, schippers en machinisten, arbeiders en polderjongens, die te zamen een groot kapitaal van kennis en arbeidsvermogen vertegenwoordigen tot de werkeloozen te behooren," het is aanneembar dat enkele takken van bedrijf en klassen van arbeiders van dien toestand den terugslag ondervinden. De droogmaking van de Zuiderzee zou verlevendiging aanbrengen, en dit bijkomstig voordeel, dat niet als de vruchten van den Zuiderzeebodem eerst over jaren zou worden genoten, doch reeds door het tegenwoordig geslacht onmiddelijk zou worden geoogst, wordt, naar zich laat verklaren, door velen hoog gewaardeerd. Dat de arbeidsvraag, die de uitvoering der onderneming in het leven zou roepen, voornamenlijk de richting der nationale productie eenigszins zou wijzigen, doch haar waarschijnlijk weinig zou verhoogen; dat de arbeiders, die aan en voor de inpoldering zullen worden te werk gesteld, bij het uitblijven darvan niet ledig langs heeren straten zullen slenteren; en dat de betere prijzen, die enkele ondernemers voor hunne voortbrengselen hopen te bedingen, uit de openbare kas zullen worden betaald, wordt meestal nauwelijks in aanmerking genomen.

Doch al is het openbaar belang, dat bij de ouderneming is betrokken, in dit opzicht ook geringer dan de propaganda, die voor de droogmaking in den lande wordt gemaakt, vaak beweert; ook afgescheiden danrvan is de inpoldering der Zuiderzee ontegenzeggelijk een grootsch plan, dat, zoo overwegende bezwaren niet van de verwezenlijking terughouden, op de meest warme ondersteuning aansprank mag maken.

I.

De bij Koniuklijk besluit van 8 September 1892 benoemde Staatscommissie tot het instellen van een onderzoek omtrent eene afsluiting en drongmaking vau de Zuiderzee heeft in een uitvoerig verslag in het algemeen zich vereenigd met het ontwerp, dat door den heer Lely als iugenieur der ZuiderzeeVereeniging is opgemaakt.

Volgens dit plan, 1) waaraan de naam van zijn ontwerper

1) Zie het bijgaand kaartje, waarvan het cliché welwillend door het Nederlandsch Landbouwcomité aan den uitgever word afgestaan. 
met groote eere is verbonden, zal de Zuiderzee door een dijk, loopende van. de Noord-Hollandsche kust over Wieringen naar Piaam in Friesland, worden afgesloten en van het aldus gevormde IJsselmeer of meer Flevo - de naam staat nog niet vast - een deel ter grootte van ongeveer 212.000 hectaren worden drooggelegd.

Deze oppervlakte zal bestaan uit vier niet aan elkander grenzende indijkingen, die ieder voor zich een polder zullen vormen en achtereenvolgens zullen worden drooggemaakt: een Noord-westelijke van 21.700 hectaren, een Zuid-westelijke van 31.520 hectaren, een Zuid-oostelijke van 107.760 hectaren en een Noord-oostelijke van 50.850 hectaren. Een aanwinst van ruim 192.000 hectaren vruchtbaar verkoopbaar land zal hierdoor worden verkregen.

Het werk kan, naar de Commissie oordeelt, in 36 jaren worden tot stand gebracht. De afsluiting van de Zuiderzee, die aan de droogmaking moet voorafgaan, kan in 9 jaren worden voltooid. De $n$. w. polder kan in het $17^{\circ}$ jaar, nadat met het werk een anvang zal zijn gemaakt, voor verkoop of ingebruikgeving gereed zijn; de z. o. in het $27^{\text {ste }}$ jaar, de z. $w$. in het $31^{\text {sie }}$ jaar en de n. 0 . in het $36^{\text {ste }}$ jaar.

De kosten van den afsluitdijk worden geraamd ruim $f 41$ millioen te zullen bedragen; die der vier inpolderingen ongeveer f 130 millioen, te zamen f 171 millioen. Hierbij komen nog voor werken van defensie f 10 millioen, voor schadeloosstelling aan de Zuiderzeevisschers, wier bedrijf door de droogmaking vernietigd zal worden, f $44_{2}^{1}$ millioen, en voor kosten van verbetering van het $\mathrm{Z}$ wolsche diep f $3 \frac{1}{2}$ millioen. Alles te zamen dus $\mathrm{f} 189$ millioen.

Rente van het aan te wenden kapitaal is hieronder niet begrepen. Bij een rentevoet van $3 \frac{1}{2}$ pCt. 's jaars, die de Staatscommissie als grondslag voor hare berekeningen aanneemt, zou het renteverlies bijna $f 90$ millioen bedragen, waardoor het totaal der kosten tot ongeveer $f 279$ millioen zou stijgen.

Neemt men aan, dat de gelden, die jaarlijks voor rente betaling noodig zullen zijn, eveneens uit leeningsgelden zullen worden betaald, of rekent men rente op rente tot aan het tijdstip, waarop de gronden volgens het plan voor uitgifte gereed zullen zijn, dan stijgt het renteverlies tot bijna f 126 
millioen en de totaalsom der kosten tot ongeveer $\mathrm{f} 315$ millioen.

Voorafgaande afsluiting is niet volstrekt noodzakelijk. Ook zonder den afsluitdijk is de droogmaking mogelijk. In dit geval zullen de dijken der vier polders zwaarder moeten zijn, doch een deel der gronden eer voor uitgifte gereed wezen, doordien onmiddellijk met de droogmaking zal kunnen worden aangevangen. De kosten der droogmaking zouden dientengevolge stijgen, doch het renteverlies zou geringer zijn. De eersten worden alsdan geraamd op $\mathrm{f} 212.700 .000$ of bijna $\mathrm{f} 24$ millioen meer dan wanneer de afsluiting plaats vindt. Het renteverlies zou evenwel slechts $f 67$ millioen bedragen of, wanneer rente op rente wordt gerekend, f 80 millioen, zoodat het totaal der kosten in zoodanig geval f 293 millioen niet zou te bovengaan.

De slotsom is dat de drooggemaakte hectare, bij berekening van rente op rente, met afsluiting van de Zuiderzee gemiddeld f 1636 en zonder afsluitdijk gemiddeld f 1522 zal kosten.

Wordt alleen rente in anmerking genomen, dan zullen de kosten per hectare in het eerste geval gemiddeld f 1449 en in het tweede gemiddeld $f 1452$ bedragen.

Wordt geene rente in rekening gebracht, dan zal de inpoldering met afsluitdijk gemiddeld $\mathrm{f} 982$ en zonder afsluitdijk gemiddeld f 1105 per hectare kosten.

In het verslag is ook nog eene andere eenigszins afwijkende berekening opgenomen. De Commissie redeneert daarbij als volgt:

De vier polders zullen op verschillende tijdstippen drooggelegd en verkoopbaar zijn.

Onderstelt men dat de verkoop plaats vindt legen een prijs, overeenkomende met het bedrag van hoofdsom en rente, dat alle gronden dooreengenomen kosten, dan zal, boven en behalve het uitgegeven kapitaal ook het bedrag der betaalde renten worden terugontvangen.

Zoo het kapitaal door geldleening is verkregen en de renten uit de gewone staatsinkomsten zijn bestreden, zou dus bij verkoop de opbrengst grooter ziju dan het voor de drongmaking der verkochte gronden geleende kapitaal.

Men zou niettemin bij verkoop van een deel ảer gronden de volle opbrengst tot aflossing van schuld kunnen besteden en dus, zoo de grouden, zoodra zij voor uitgifte gereed waren, tegen den bedoelden prijs werden te gelde gemakt, uit de 
opbrengst van een polder niet alleen het voor de droogmaking van dezen polder aangewende kapitaal, maar ook uit de terugontvangen renteu voorshands een deel van het voor de nog niet dronggemaakte gronden geleende bedrag kunnen delgen, of het bedrag dier renten voor de voltooing dezer polders kunnen bezigen.

Men zou op deze wijze allereerst het geleende kapitaal geheel aflossen, alvorens aan de schatkist de door haar voorgeschoten rente terug te betalen; als het ware langs dien weg van de schatkist uit de opbrengst van verkochte gronden een renteloos voorschot verkrijgen tot het bedrag der door haar betaalde renten van het voor deze gronden opgenomen kapitaal; en het totale renteverlies zou dientengevolge uit den aard der zaak beneden de vorige raming blijven.

De kosten zouden volgens deze wijze van berekening, ingeval van inpoldering met afsluitdijk, slechts $f 260$ millioen of gemiddeld $f 1350$ per hectare bedragen, eu ingeval van inpoldering zonder afsluiting, f 262 millioen of gemiddeld $\mathrm{f} 1360$ per hectare.

Ten slotte wordt in het verslag ook nog becijferd wat de droogmaking zou kosten, zoo rente op rente wordt berekend en de polders, zoodra zij voor uitgifte gereed zijn tegen een prijs, overeenkomende met het bedrag, dat de gronden gemiddeld met rente op rente kosten, worden verkocht. De kosten zouden in dit geval bedragen, zoo de afsluitdijk wordt gelegd, f 312 millioen of gemiddeld $f 1620$ per hectare, en zoo de afsluiting niet plaats vond, f 293 millinen of gemiddeld f 1520 per hectare.

In hoeverre de onderstellingen, waarop deze berekeningen gebaseerd zijn, gewettigd zijn, zal later blijken. Voorshands bepaal ik mij tot het noemen der cijfers, waarvan eene korte recapitulatie waarschijnlijk niet onwelgevallig is.

De kosten worden geraamd:

Bij inpoldering met afsluiting.

\begin{tabular}{|c|c|c|}
\hline $\begin{array}{l}\text { Zonder rente } \\
\text { Met rente } \\
\text { Met rente op rente }\end{array}$ & $\begin{array}{l}\text { Totaal } \\
\text { f } 189.000 .000 \\
\text { f } 278.835 .725 \text { of } \mathrm{f} 259.794 .000 \\
\text { f } 314.909 .627 \text { of } \mathrm{f} 311.753 .000\end{array}$ & $\begin{array}{l}\text { gemiddeld per H.A. } \\
\text { f } 982 \\
\text { f } 1449 \text { of } f 1350 \\
\text { f } 1636 \text { of } f 1620\end{array}$ \\
\hline \multicolumn{3}{|c|}{$\mathrm{B}$ ij inpoldering zonder afsluiting. } \\
\hline $\begin{array}{l}\text { Zonder rente } \\
\text { Met rente } \\
\text { Met rente on }\end{array}$ & $\begin{array}{l}\text { Totaal } \\
\text { f } 212.700 .000 \\
\text { f } 279.410 .000 \text { of } f 261.718 .000 \\
f 292.925 .244 \text { of } f 292.509 .000\end{array}$ & $\begin{array}{l}\text { gemiddeld per H.A. } \\
\text { f } 1105 \\
\text { f } 1452 \text { of } f 1360 \\
\text { f } 1522 \text { of } f 1520\end{array}$ \\
\hline
\end{tabular}


De kosten van publieke gebouwen, gemeentehuizen, posten telegraafkantoren, scholen enz ${ }^{1}$ ) waarvoor de Staat zal moeten zorgen, zijn onder deze cijfers niet begrepen; zij worden geraamd f $\mathbf{5}$ per H.A. te zullen bedragen.

Aan het einde van haar onderzoek kwam de Staatscommissie met groote meerderheid van stemmen tot het beslnit, dat de afsluiting en de droogmaking op eene wijze als door de Zuiderzee-Vereeniging is voorgesteld, in 's Lands belang behoort te worden ondernomen. Zes leden vereenigden zich niet met deze conclusie. ${ }^{2}$ )

Omtrent de wijze, waarop het werk eventueel ten uitvoer zou moeten worden gebracht, was geen verschil van gevoelen. Eenstemmig was men van oordeel, dat dit zou behooren te geschieden, niet bij wijze van concessie, maar door den Staat.

II.

De vraag of eene afsluiting van de Zuiderzee aan de inpoldering hehoort vooraf te gaan is geenszins eene quaestie van ondergeschikte beteekenis, die alleen de uitvoering betreft.

Tusschen de beide plannen bestaat groot verschil, ook in omvang en strekking.

1) Voor het bouwen van woningen zal de Staat bovendien naar het voorstel der Commissie een voorschot van f 200 per II.A. geven, die de kooper of erfpachter door middel van eene annuiteit zal moeten terugbetalen.

2) Voor stemden de heeren W. F. Leemans, Mr. C. J. Sickesz, Dr. Th. H. Mac Gillarry, P. A. Bos, C. ten Bosch, J. Breebaart Kz., K. Eland, D. Fontein de Jong, A. M. J. Hendrichs, A. H. Hoekwater, $\mathrm{Mr}$. Ph. A. Holsboer, H. C. van der Houven van Oordt, W. Hovy, Mr. B. H. Pekelharing, Dr. R. H. Saltet, Mr. H. Smeenge, J. M. Telders, S. J. Vermaes, A. J. Voorduin, A. C. Wertheim, en A. D. Zur Mühlen.

Tegen de heeren Mr. M. Mees, Mr. E. N. Rahusen, Mr. F. S. van Nierop, Mr. J. D. Veegens, J. W. Welcker, en J. M. F. Wellan.

De voorzitter der Commissie, de Minister van Waterstaat, Handel en Nijverheid de heer C. Lely nam aan de stemming geen deel.

De heer W. van Konijnenburg werd door ziekte verhinderd de laatste bijeenkomst bij te wonen. 
Met partieele droogmaking, zooals eene inpoldering zonder afsluiting wordt genoemd, wordt alleen landaawwinning beoogd.

Door voorafgaande afsluiting der Zuiderzee zal gelegenheid worden gegeven dezelfde oppervlakte onder gunstiger omstandigheden in te dijken en tevens eene uitgestrektheid vau 145.000 hectaren van het overblijvende deel der zee in een zoet watermeer worden herschapen, waardoor de toestand van den waterstaat der omliggende provincien belangrijk zal worden verbeterd en andere gewichtige voordeelen zullen worden verkregen.

Op het meer, dat een vrij standvastig laag peil zal hebben, zullen de Vechtboezem, de Eem, de polders langs den Beneden IJssel, het Zwarte water, de Overijsselsche Vecht, de Linde enz. beter kunnen waterloozeu dan op den afwisselenden stand der Zuiderzee, en het doorgaand lager peil van het meer zal eene verbeterde gelegenheid geven om schadelijke hooge standen van Friesland's boezem te voorkomen.

De bezuiden den afsluitdijk gelegen landen zullen geene stormvloeden te duchten hebben. De zeedijken, die hen thans tegen het water beveiligen, zullen, voorzooverre zij niet achter de indijkingen binnendijken worden, meerdijken worden en voortaan minder onderhoudskosten vorderen. De kosten voor de Drontherbedijking zullen kunnen worden bespaard, de veiligheid van de nienwe polders zal beter verżekerd zijn, de polderlasten zullen lager zijn, de IJsseldijken beneden $W$ ijhe zullen bij storm, gepaard met hoog opperwater, worden ontlast en de tegen de zee te verdedigen kustlijn zal belangrijk verkort worden.

Door de afsluiting zal zich in het afgesloten deel minder ijs vormen. De verschillende havens aan de Zuiderzee zullen in gunstiger toestand komen, en aan het sints jaren aanhangige vraggstuk van de verbetering van het $\mathrm{Zwolsche}$ Diep zal eene afdoende oplossing worden gegeven.

Ook voor de waterverversching van de drooggemaakte gronden van Noord-Holland en inzonderheid van Friesland zal de afsluiting van groote beteekenis zijn. De polders zullen bij het schutten zoet water ontvangen, waardoor het drinkwater van het vee op vele plaatsen langs de Zuiderzee zal verbeteren.

Daarbij zal het standvastige peil van het meer voor de scheepvaart voordeelig zijn, en het aangenomen peil op de schutting te Schellingwoude van gunstigen invloed wezen. 
Voorts opent de afsluitdijk de mogelijkheid eene onafgebroken spoorwegverbinding tussehen Holland en de Noordelijke provincien tot stand te brengen, en sluit hij ingeval van oorlog het meer voor de vijandelijke marine. Inzonderheid voor de verdediging is hij bijna onmisbaar. Hij beschermt de stelling van Amsterdam tegen een aanval van gepantserde schepeu en geeft gelegenheid om den vijand te verhinderen troepen nit Friesland en Noord-Holland over het IJsselmeer over te brengen.

En terwijl al deze voordeelen worden verkregen, zal tengevolge van de voorafgaande afsluiting de droogmaking regelmatiger en met minder risico kunnen worden nitgevoerd, de duur, die de uitvoering der werken met inbegrip van den dijk zal vorderen, niet belangrijk langer wezen en het totaal der kosten - wanneer de renten buiten rekening blijven - geringer zijn dan ingeval van partieele inpoldering.

En ten slotte zullen dan tevens de bezwaren, die in de Noordelijke provincien tegen vroegere ontwerpen tot indijking van het zuidelijk deel der Zuiderzee zijn gerezen, vervallen, en in plaats van den tegenstand de steun dezer gewesten worden verkregen wegens de voordeelen, die de afsluiting der Zuiderzee voor de dijkverdediging, waterverversching en verbetering der communicatie medebrengt.

$\mathrm{Na}$ ongeveer op deze wijze de beide plannen tegenover elkander gesteld te hebben - waarbij het risico verbonden aan het leggen van den afsluitdijk geringer wordt geacht dan dat van het maken van vier zeedijken - is de keuze voor de Commissie niet twijfelachtig. Partieele droogmaking kan haar niet bekooren. "Het groote werk krijgt, dus zegt zij, eerst zijne volle waarde en beteekenis door de voorafgaande afsluiting der Zuiderzee." Liet men de groote voordeelen, die de afsluiting zou hebben aangebracht, verloren gaan, men zou "nog niet eens kunneu spreken van eene zuinigheid, die de wijsheid bedroog; want men zou feitelijk een duurder werk hebben gemaakt, dat minder winsten en voordeelen zou hebben opgeleverd." Bij de beraadslagingen in de Commissie-vergaderingen werd dit door verschillende leden nog met meer klem betoogd. Partieele inpoldering werd genoemd werkverschaffing in den slechten zin van het woord, en de voorspelling werd gedaan, dat zoo een paar polders gereed zouden zijn, eene algemeene 
afkeuring zich zou doen hooren, wanneer de afsluiting ware nagelaten Het gansche plan van de drongmaking staat of valt, naar een der sprekers verklaarde, met den afsluitdijk.

Droogmaking der Zuiderzee is dus volgens de Commissie inpoldering na voorafgaande afsluiting. De afsluitdijk en de vier polders vormen é́n geheel, dat in zijn geheel beoordeeld behoort te worden. De afsluitdijk is geen zelfstandig werk, maar een onderdeel, waarvan de kosten over de in te dijken gronden behooren te worden omgeslagen en gezegd worden teruggevonden te zullen worden, doordien, werd hij niet gelegd, de dijken der verschillende polders aanzienlijk hoogere uitgaven zullen vordereu.

Partieele indijking wordt zelfs niet subsidiair aanbevolen, voor het geval dat het uitverkoren plan regens het risico verbonden aan het leggen van den afsluitdijk of den buitengewonen omvang der onderveming op onoverkomelijke bewaren mocht stuiten.

\section{III.}

Allereerst dient wel behoorlijk te worden vastgesteld wat de afsluiting en droogmaking vermoedelijk zullen kosten.

De raming, aan de hand van de begrooting van den heer Lely door de deskundige leden der Commissie met groote zorg opgemaakt, nemen wij, zooals van zelf spreekt, als juist aan. Het behoort niet tot onze taak hare cijfers, waaraan wij trouwens geen reden hebben te twijfelen, na te gaan, doch wel behooren wij te beslissen, of ook renten behooren in rekening te worden gebracht en rente op rente behoort te worden gerekend.

De Staats-Commissie laal zich hieromtrent niet pertinent uit. $\mathrm{Z}_{\mathrm{ij}}$ berekent de kosten, zonder rente, met rente, en met rente op rente, en geeft als hare meening te kennen, dat de Stant een nuchtere financiëele politiek moet voeren en niet minder dan een particulier eene zoo zuiver mogelijke balans moet opmaken. ' $\mathrm{ij}$ gaat zelfs verder en verklaart, dat le Strat de droogmaking niet zou mogen ondernemeu als de balans niet met een roordeelig saldo sloot. Doch met dit alles worlt door haar nog geenszins toegegeven, dat eene zuiver commerciëele berekening met rente juist zou zijn. Zij herinnert dat 
het Rijk tot dusverre bij de uitvoering van groote werken nog nooit rente op rente of zelfs rente heeft gerekend, en betwijfelt of de financiëele zijde van het Zuiderzeevraagstuk wel naar waarheid zuiver wordt voorgesteld, wanneer men den Staat de rekening laat opmaken, als betrof het eene industriëele onderneming. De Staat, dus zegt zij, is geen particulier. Hij geniet tot in lengte van tijd van de zich telkens vermeerderende en zich ontwikkelende indirecte voordeelen, die aan een particulier of aan een particuliere ouderneming in geen enkel opzicht ten goede komen Tegenover het karakteristiek tijdelijke van renten staan de tot in een onbegrensd verschiet voldoende revenuën van den Staat.

Is dit betoog wel juist?

Dat de Staat tot in verre toekomst voordeel van zijne onderneming zal genieten is geen reden om de offers, waardoor dit voordeel verkregen zal worden, niet nauwkeurig vast te stellen. En al zouden renten de eigenaardigheid hebben slechts tijdelijk te zijn - hetgeen bezwaarlijk aan de Commissie is toe te geven - dit neemt niet weg, dat zij, zoolang zij verschuldigd zullen zijn, betaald zullen moeten worden en dus moeielijk geheel verwaarloosd kunnen worden.

$B$ ij de beantwoording der vraag, of renten in rekening moeten worden gebracht, zou men, naar het mij voorkomt, hoogstens kunnen onderscheiden, naar mate de middelen tot bestrijding der kosten uit de gewone staatsinkomsten dan wel door leeningen gevonden zullen worden.

Naar economische en commerciëele regelen behoort de kapitaalrente tot de voortbrengingskosten, onverschillig of de ondernemer eigen kapitaal heeft gebezigd of kapitaal heeft geleend. En al is de Staat niet gewoon beschikbare gelden rentegevend uit te zetten, er zou, ook al werden de kosten der droogmaking uit gewone middelen bestreden, renteverlies kunnen zijn, in zooverre de voor de Zuiderzee besteedde gelden, waren zij hiertoe niet gebezigd, tot delging van staatsschuld hadden kunnen dienen of van de belastingschuldigen niel gevorderd hadden behoeven te worden, waardoor deze dan in de gelegenheid zouden zijn geweest meer te sparen. Doch ik wil niet doctrinair zijn en ben bereid met deze eventualiteiten geen rekening te houden, omdat het toch uiet 
vaststaat dat deze gelden alsdan door den Staat niet waren gebezigd tot nitgaven, die evenmin renten afwierpen, of dat de belastingschuldigen hetgeen zij uninder aan belastingen hadden te betalen, werkelijk hadden opgelegd en niet verteerd.

Lang er over te twisten wat in zoodanig geval behoorde plaats te vinden is echter onnoodig, want dat de kosten uit gewone middelen zullen worden bestreden is onaannemelijk. De Staat zou dan gedurende de droogmaking tot dit doel jaarlijks eene som van gemiddeld $f \dot{b}$ millioen moeten beschikbaar houden, of gesteld al dat het, zooals bij de laatstgenoemde wijze van berekening wordt aangenomen, gelukte de ingedijkte gronden, zoodra zij voor uitgifte gereed waren, voor den kostenden prijs te gelde te maken, althans gedurende de eerste 16 jaren gemiddeld ruim $\mathrm{f} 6{ }_{2}^{1}$ millioen voor het werk moeten bestemmen. De tijd der Indische baten, waaruit een groot deel der spoorwegen werd gebouwd, is voorbij en zal niet licht weder keeren. En de toestand der financien is niet van dien aard, dat op een jaarlijksch overschot $\operatorname{van} f 6_{2}^{1}$ of 5 millioen kan worden gerekend, dat voor de droogmaking kan worden ter beschikking gesteld. Het kost den minister van financien in den regel reeds vrij wat moeite de middelen met de uitgaven in evenwicht te brengen. Ter wille van de droogmaking de belasting te verhoogen zal nauwelijks doenbaar zijn. Over den druk der belastingen wordt reeds, en inderdaad niet ten onrechte, zeer geklaagd, en vrij wat dringender volksbelangen dan de droogmaking der Luiderzee, die geene geringe eischen aan de schatkist zullen stellen, - men zie slechts de programma's der politieke partijen - wachten nog op bevrediging. De volksvertegenwoordiging zal onder deze omstandigheden wel niet bereid worden gevonden voor voordeelen, die eerst na verloop van jaren zullen wordeu geoogst, van de belastingschuldigen grootere offers te vergen. Zij zal het tegenwoordig geslacht niet willen belasten om aan de nakomelingen in den vorm van eene drooggemaakte Zuiderzee een onbezwaard kapitaal na te laten. Veeleer zal zij het billijk achten, dat waar de laatsten de vruchten zullen genieten, zij ook, voorzooverre met een voorzichtig financieel beheer te verantwoorden, de lasten dragen. Het is dus eene ntopie te gelooven, dat de kosten der droogmaking uit de gewone middelen zullen worden 
gevonden. En waar het mitsdien vrij wel vast staat, dat zoo niet juist ten behoeve, in elk geval ten gevolge van de droogmaking aanzienlijke sommen zullen worden geleend, zullen de renten moeten worden betaald, en verhoogen zij - al is het Rijk ook niet gewoon bij de raming van openbare werken op renteverlies te letten - de kosten der onderneming.

De geschiedschrijver van de droogmaking van het Haarlemmermeer 1), Jhr. Gevers van Endegeest, stelt de uitgaaf, die deze onderneming voor den Staat medebracht op $\mathrm{f}$ 13.789.377, doordien hij daaronder $f 4.411 .865$ voor kosten en renten der tot dit doel gesloten geldleening begrijpt, en berekent dat de onderneming een nadeelig slot van f 4.412.115 heeft gelaten, hoezeer de kosten der werken, wanneer het renteverlies wordt buiten aanmerking gelaten, door de opbrengst der gronden en andere baten werden gedekt. Wie zich eene ware voorstelling wil maken van de kosten, die de droogmaking der Zuiderzee zal eischen, moet dit voorbeeld volgen. Het schitterendst betoog kan den last der rentebetaling niet wegredeneeren.

Dat de Staat bij de raming van kosten van openbare werken geene rente in rekening brengt, doet dus voor de beantwoording der vraag, die ons bezighoudt, weinig ter zake, doch al zou de door hem gevolgde wijze van rekenen in het algemeen gewettigd zijn, ook dan nog mag men niet voorbij zien, dat de droogmaking der Zuiderzee niet op éen lijn kan worden gesteld met de werken, waarop men zich beroept. Deze werken strekten oin te voorzien in eene publieke behoefte, die bevrediging eischte. Het openbaar verkeer vorderde den aanleg der spoor- en waterwegen. De laatste werpen geene directe baten af. Zij zijn vrij van tollen. Het renteverlies, dat tot de voltooiing van den Rotterdamschen waterweg of van het Merwede kanaal zou worden geleden, na te gaan, had weinig praktisch belang, want ook nadat zij tot stand gebracht zouden zijn, zou de schatkist daarin moeten voorzien. En waar de openbare werken ook directe inkomsten zouden afwerpen, was hunne rentabiliteit van ondergeschikte beteekenis. Of de aanleg der spoorwegen eenige millioenen meer of minder zou kosten, of en in hoeverre de opbrengst der verschillende lijnen zou opwegen

1) Over de droogmaking van hot Haarlemmermeer III p. 178. 
tegen de lasten, die de bouw voor den Staat zou medebrengen, was voor den aanleg niet beslissend.

De droogmaking van de Zuiderzee heeft een ander karakter. $\mathrm{Al}$ is zij geen zuiver industrieele onderneming, in zooverre niet beoogd wordt met den verkoop of de exploitatie der in te polderen gronden winst te behalen, zij is daarmede zeer verwant. Geen openbaar belang vordert hare uitvoering. Zij verschilt in dit opzicht zelfs van eeue onderneming, waarmede zij overigens veel overeenkomst heeft: de droogmaking van het Haarlemmermeer. Dit werk, waarover met hollandsche bedachtzaamheid tweehonderd jaren is gedebatteerd - Leeghwater had in zijn bekend Haarlemmermeerboeck de droogmaking reeds krachtig voorgestaan - was noodig om aan de steeds voortwoekerende afslijting der omliggende landen een einde te maken. Het meer breidde zich voortdurend uit. Stormweder had de wateren reeds vób́r de poorten van Amsterdam gebracht. Afgescheiden van de voordeelen, die de droogmaking zou geven, was het geboden haar te ondernemen, om ernstige schade voor den omtrek te voorkomen.

De Zuiderzee is rustiger van aard, ten minste gemakkelijker in bedwang te houden. Al is zij enkele malen ook buiten hare grenzen getreden, de veiligheid van het land eischt hare droogmaking niet. Hierover zijn alle deskuudigen het eens. De droogmaking wordt alleen aanbevolen wegens de directe en de indirecte voordeelen, die zij belooft. Met het oog op de laatsten, op den gunstigen invloed, dien zij op de volkswelvart en andere openbare belangen zal uitoefenen, behoeft de ouderneming geen winst te laten. De Staat mag zelfs, wanneer hij de indirecte voordeelen, die zij in het verschiet stelt, in aanmerking neeint, zich voorshands eenig geldelijk verlies getroosten; doch de warmste voorstander van de droogmaking moet nog aantoonen, dat deze indirecte voordeelen van dien aard zullen zijn, dat het er niet toedoet of de kosten verscheiden millioenen meer of minder zullen bedragen, en dat het voor de belastingschuldigen onverschillig zou zijn of zij gedurende de inpoldering belangrijke sommen aan rente zulleu moeten opbrengen. Het gaat dus niet aan de onderneming te anvaarden, zonder dat men zich behoorlijk zal hebben rekenschap gegeven van de offers, die zij nu en later van de 
natie zal vragen. In tegenstelling van hetgeen bij de meeste openbare werken plaats vond, wordt de droogmaking der Zuiderzee in boofdzaak door het bedrag der kosten beslist. De lasten, die zij zal medebrengen, moeten dus zoo nauwkeurig doenlijk worden vastgesteld, en dit doet men niet, wanneer men uitsluitend de arbeidsloonen en kosten van aankoop van materialen en werktuigen in rekening brengt, doch de renten, die men van de op te nemen gelden zal moeten betalen, veronachtzaamt. Vooral niet, waar het werk van buitengewonen duur zal zijn en de renten eene som van groote beteekenis zullen uitmaken.

Uit dit alles volgt echter geeuszins, dat de renten, zooals aanvankelijk bij de droogmaking van het Haarlemmermeer is geschied, ook uit leeningsgelden moeten worden betaald. De renten zijn een uitgaaf en een gevolg der onderneming en behooren dus tot hare kosten, om het even of zij uit gewone middelen dan wel nit de opbrengst van leeningen worden bestreden. Het verschil is slechts dat in het eerste geval de tegenwoordige belastingschuldigen reeds spoedig, nadat met het werk een aanvang zal zijn gemaakt, voor een deel der kosten zullen moeten opkomen, en dat in het laatste geval alle kosten, inclusief de renten, ten laste van het nageslacht zullen blijven. Waarschijnlijk zal het eerste plaats vinden. Het moge voor de belastingschuldigen een bezwaar zijn, dat mettertijd zelfs ernstig kan worden, en principieel mogen hiertegen dezelfde argumenten kunnen worden angevoerd, als zooeven tegen de bestrijding der kosten uit de gewone middelen werden ontwikkeld, het zon niet weinig bedenkelijk zijn anders te handelen. De staatsschuld jaarlijks met het bedrag der gestadig aangroeiende rente te vermeerderen, zou financieel moeilijk te verantwoorden ziju, te meer daar nen nimmer zeker is, dat het werk in den gernamden tijd zal worden tot stand gebracht.

Mag men dus aannemen dat de renten der leeningen uit de gewone staatsinkomsten zullen worden betaald, dan mag bij de raming van kosten de rentelast, dieu de droogmaking zal medebrengen, niet uit het oog worden verloren. Renten van renten kunnen in dit geval evenwel buiten aanmerking blijven. ${ }^{1}$ ).

1) Bij het wetsontwerp tot bedijking en droogmaking van een gedeelte der Zuiderzee. en het maken van een waterweg van AmsterECUN. 1897. 
IV.

De renteberekening der Commissie is in verband tot den koers der staatsfondsen tijdens de vaststelling van haar verslag gebaseerd op den rentevoet van $3 \frac{1}{2}$ pCt. 's jaars.

Middelerwijl is de rentestand gedaald. De $3 \frac{1}{2}$ pCt. staatsschuld is in een 3 pCt. fonds geconverteerd, en mogelijk is het dat het peil der rente verder zal vallen. De geschiedeuis leert dat in normale tijden bij het toenemen der welvaart de

dam naar de Waal, in April 1877 door de regeering ingediend, was behalve eene begrooting van de kosten der droogmaking ook eene globale raming van uitgaven en ontvangsten der onderneming gevoegd.

\section{Ditgaven:}

Geraamd werden de

Voor de werken . . . . . . . . . . . f 116.000 .000

Voor renten der geleende gelden . . . . . 47.249 .680

Voor aflossing van leeningen . . . . . . $\$ 94.100 .000$

Ontrangsten :

f 257.349 .680

Gelden door leening verkregen f 92.218 .000

Opbrengst der gronden (à $\mathrm{f} 1000$

per hectare) . . . . . . $\$ 137.280 .000$

Nadeelig verschil . . f 27.851 .680

De regeering was dus ook van oordeel, dat bij dit werk de rentelast wel degelijk in aanmerking kwam.

In de memorie van toelichting schrijft zij evenwel, na den staat van ontrangsten en uitgaven kort als hierboven te hebben gerecapituleerd: koo men de renten der geleende gelden, die waarschijnlijk uit de gewone staatsinkomsten worden gevonden, buiten de berekening laat, zou in stede van voormeld nadeelig versohil, een overschot van f19.398.000 worden verkregen, dat echter grootendeels door de vermeerderde uitgaven voor de defensie zou worden opgewogen".

Deze redeneering is niet logisch, doch er is tegen haar nog een ernstigere grief. In 1878 was het reeds noodig eene leening te sluiten, en in 1883 en 1884 geschiedde dit wederom. Is er meer noodig om te bewijzen hoe onbedachtzaam het zou zijn geweest de renten, die, zoo niet tot vermeerdering van schuld, in elk geval tot verhooging van belasting aanleiding zouden hebben gegeven, buiten aanmerking te laten? 
rentestand neiging heeft te dalen. Reeds in de zeventiende eeuw vond in de vredejaren herhaaldelijk eene conversie der schuld van Holland en West-Friesland plaats. Prins Maurits bracht de rente van $6 \frac{1}{2}$ pCt. op 5 pCt., Johann de Witt in 1655 op 4 pCl., en bij het einde der eeuw bedroeg zij niet meer dan $2 \frac{1}{2}$ pCt. à 3 pCt. In de volgende eeuw, die over het algemeen rustiger was, steeg de koers der 3 pCt. Hollandsche obligatien vaak boven pari, in 1774 zelfs tot 110 pCt. De fransche omwenteling met al haar nasleep bracht uit den aard der zaak een geweldige reactie te weeg. Omstandigheden, die eene buitengewone vraag naar kapitaal doen ontstaan of de kapitaalvorming tegenhouden, doen den rentestand rijzen. Nadat evenwel de rust in Europa was hersteld, werd het verloop, zij het ook aanvankelijk langzaam, wederom hetzelfde als te voren. Eerst in 1845 vond eene trouwens zeer verklaarbare rijzing plaats, die tot het einde van den fransehduitschen oorlog aanhield. De toepassing van de stoomkracht op ruime schaal, de bouw van spoorwegen, stoombooten en fabrieken, de aanleg van telegraaflijnen, en verschillende snel op elkander volgende oorlogen deden de vraag naar kapitaal sterk toenemen. In vijf en twintig jaren werd door den aanleg van allerlei middelen van versnelde gemeenschap meer tot bevordering van het verkeer tot stand gebracht dan in eeuwen op dit gebied was verricht. Reusachtige kapitalen werden in dien tijd tot dit doel beschikbaar gesteld, terwijl bijna gelijktijdig niet weinig kapitaal werd verwoest. Het korte tijdvak van het tweede fransche keizerrijk was getuige van zes groote oorlogen. Onder den invloed van den vrede en van de gestadige vermeerdering van kapitaal is echter in de laatste twintig jaren wederom eene daling van den rentestand ingetreden. 1) De aanwas van kapitaal was in dien tijd bijzonder sterk, sterker dan de groei der bevolking ${ }^{2}$ ), en waar het

1) Dr. Julius Kahn. Geschichte des Zinsfusses in Deutschland seit 1815 und die Ursachen seiner Veränderung.

2) De engelsche statisticus Robert Giffen berekent dat het vermogen in het Vereenigd koningrijk van Groot-Brittanje en Terland per hoofd der bevolking in 1845 pd. st. 143 , in 1865 pd. st. 200 , in 1875 pd. st. 260 , en tien jaar later, schoon de landprijzen middeler- 
nieuwe kapitaal, dat onafgebroken gevormd werd, voor de toepassing van nieuwe uitvindingen van beteekenis geen buitengewone vraag ontmoette, en ook betrekkelijk weinig kapitaal door oorlog werd vernietigd, moest het zich wel allengs minder gunstige voorwaarden laten welgevallen dan te voren konden worden bedongen. Zoo daalde de rentestand, en kon hij licht verder dalen en de verwachting van Paul Leroy Beaulieu'), Adolf Wagner ${ }^{2}$ ), d'Aulnis de Bourouill ${ }^{3}$ ) en andere staathuishoudkundigen van gezag zich wel eeus verwezenlijken, dat de tijd niet ver verwijderd is, waarop de rentestand, zij liet ook na eenige schommelingen, tot 2 pCt. en zelfs lager zal vallen.

wijl waren gedaald, pd. st. 270 bedroeg. Zie zijn werk The growth of capital.

In de Vereenigde Staten van Noord-Amerika wordt het vermogen gerekend pex hoofd der bevolking te hebben bedragen in 1850 $\$ 108$, in $1860 \$ 514$, in $1870 \$ 780$, in $1880 \$ 870$ en in $1890 \$ 1036$ (Statistical abstract of the United States).

Omtrent de vermeerdering van het volksvermogen in andere landen vindt men eenige bijzonderheden in de Debersichten der Weltwirthschaft van Dr. Franz von Juraschek. (18851889) pag. XVI.

Voor zooverre men uit de gegevens der successiebelasting, die evenwel slechts een gebrekkige maatstaf zijn, mag besluiten, schijnt de vermeerdering van het volksvermogen hier te lande in den laatsten tijd weinig belangrijk te zijn geweest. Intusschen is de rentestand, ook al onder den invloed van de kapitaalsvermeerdering in het buitenland, in het algemeen zeker sterk gedaald.

1) Paul Leroy Beaulieu. Essai sur la répartition des richesses et sur la tendance à une moindre inégalité des conditions. p. 257. «Nous regardons, quant à nous, comme très vraisemblable que dans un délai d'un quart ou d'un demisiècle, l'intérêt des capitaux dans l'Europe occidentale tombe à 1 et demi ou 2 p. 100 pour les placements à long terme de première sécurite. Il faudrait que les contrées neuves, par exemple l'Afrique, fussent très promptement mises en oeurre par les capitaux européens pour qu'on évitat cet avilissement de l'intérêt.»

$\left.{ }^{2}\right)$ Lehr und Handbuch der politischen Oekonomie I. \& $167\left(3^{\mathrm{e}} \mathrm{ed}\right.$. pag. 392).

3) De daling van den rentestand, haar oorzaken en haar naaste toekomst. Economist 1888, pag. 803 . 
Op het besluit van den Staat ten aanzien van de droogmaking zal de rentestand van geen geringen invloed zijn. De rentelast, dien het werk reeds spoedig op de schouders der natie zal leggen, zal de regeering en volksvertegenwoordiging in elk geval lang doen aarzelen de onderneming te aanvaarden. De daling van den rentestand, waardoor de raming van kosten reeds met een zevende van het voor rente uitgetrokken bedrag kan worden verminderd, heeft de kansen der droogmaking doen stijgen, en met iedere verdere daling zal dit wederom plaats vinden.

Het renteverlies is echter niet alleen af hankelijk van den rentevoet, maar ook van den duur der uitroering, en de Commissie let weinig of niet op omstandigheden, die de voltooiing van het werk konden vertragen. Zij neemt aan, dat de gronden in cultuur zullen worden gebracht op het tijdstip, waarop dit, zoo met het werk ongestoord wordt voortgegaan, mogelijk zal zijn. Doch allerlei gebeurtenissen, onvonrziene moeielijkheden, die zich bij de uitvoering kunnen voordoen, zelfs politieke omstandigheden, geheel vreemd aan de onderneming, kunnen in de vele jaren, die tusschen het begin en de voltooiing zullen verloopen, teleurstelling aanbrengen. Het is een gewoon verschijnsel, dat de uitvoering van groote werken meer tijd vordert dan aanvankelijk werd ondersteld, en in het bijzonder bij droogmakingen schijnt dit voor te komen. Honderd jaren geleden werd reeds door het Bataafsch Genootschap te Rotterdam deze prijsvrang uitgeschreven: Welke zijn de redenen, dat de droogmakingen veel langer duren en veel meer kosten na zich slepen dan men vooraf had berekend. De vraag had geen gevolg. $\mathrm{Z}_{\mathrm{ij}}$ bleef onbeantwoord en het vraagstuk onopgelost. De verklaring, in lateren tijd door Baron van Lijnden van Hemmen gegeven, dat de wind, die de molens in beweging bracht, allengs in kracht zou zijn verminderd en korter zou aanhouden dan voorheen, kan niet bevredigen ${ }^{1}$ ). Want ook de droogmaking van het Haarlemmermeer, die door stoom geschiedde, duurde langer dan aanvankelijk was geraamd. In het tweede deel

1) Verhandeling over de droogmaking van de Haarlemmermeer, pag. 74 . 
van het werk van Jhr. Gevers van Endegeest: Over de droogmaking van het $\mathrm{Haarlemmermeer}$ wordt aan De vertragingen zelfs een bijzonder hoofdstuk gewijd, en het derde deel, dat acht jaren later verscheen, bevat wederom een hoofdstuk met het opschrift Vervolg der vertragingen, dat hierover handelt. Allerlei onvoorziene omstandigheden waren oorzaak, dat de droogmaking, die men meende in 12 jaren ten uitvoer te zullen brengen, eerst 7 jaren later gereed kwam. Men moge zich vleien, dat thaus de droogmaking der Zuiderzee en de uitgifte harer gronden geleidelijk volgens het programma zullen plaats vinden; wie niet bedrogen wil uitkomen, doet wel met hetgeen het verleden leert, en, ik zou hast schrijven, ook wederom bij de sluis te IJmuiden werd ondervonden, rekening te houden. Al schijnt het ook doenbaar de droogmaking in minder dan 36 jaren tot stand te brengen, en al is deze termijn slechts gekozen om niet verplicht te zijn jaarlijks meer dan 10.000 hectaren uit te geven, licht kon het langer duren eer de gronden drooggelegd en rentegevend zullen zijn; en hoewel eene langzamere uitvoering van het werk of uitgifte van gronden het renteverlies niet evenredig zal doen stijgen, eene latere oplevering zal altijd, hetzij dan in mindere of in meerdere mate, èn het renteverlies èn de kosten van uitvoering verhoogen.

Zoo zijn er naast de goede kansen, die den druk van den rentelast konden verlichten, ongunstige die den duur konden verlengen.

V.

Hoe staat het nu met de baten der onderneming? Mag men aannemen dat de waarde der in te dijken gronden de kosten der droogmaking zal dekken, wellicht zelfs overtreffen, of zal de rekening met een verlies sluiten en zou dit verlies belangrijk kunnen zijn?

Indien wij niet eenvoudig op goed geluk ons zelven en onze kinderen voor langen tijd en tal van millioenen willen engageeren, dienen deze vragen onder de oogen te worden gezien. Een beraden financiëele politiek laat niet toe eene 
onderneming, waarbij f 280 millioen gemoeid kunnen zijn, te aanvaarden, zonder zich zoo goed doenlijk van de uitkomsten, die zij voor de schatkist zal opleveren, rekenschap te hebben gegeven. Het is niet voldoende te weten dat door de droogmaking, behalve verschillende indirecte voordeelen, 190.000 hectaren vruchtbaren grond verkregen zullen worden. De. ontginning van een goudmijn kan ook verlies geven. Wie met kennis van zaken wil oordeelen, dient zooveel mogelijk te onderzoeken, welke waarde de nieuwe polders zullen hebben, en, zoo deze niet nauwkeurig mocht zijn vast te stellen, als een verstandig ondernemer de gunstige eu kwade kansen zoo goed doenlijk na te gaan.

De verkoopwaarde der gronden op het tijdstip, dat zij voor uitgifte gereed zullen zijn, is moeilijk onder betrouwbare cijfers te brengen. Waar de Staatscommissie zelve beweert dat de grootste deskundige op het gebied van waardeering van gronden zich daaraan niet zal wagen, uit vrees van zich in de oogen van ieder ander deskundige belachelijk te maken, en aan iedere schatting alle vertrouwen ontzegt, kan elke poging om de baten der onderneming op dezelfde wijze als hare lasten te ramen, vrij wel als een nutteloos werk worden beschouwd.

Eer laat zich, naar de Commissie meent, een denkbeeld van de productiviteit van den bodem vormen, en aan de hand van de schattingen van de commissiën, die indertijd belast waren met de herziening van de belastbare opbrengst van de ongebouwde eigendommen, wordt dan ook de geldelijke opbrengst der nieuwe polders in het Verslag nagegaan en dooreengenomen op $f$ 60.- per hectare 's jaars geraamd. En is deze schatting juist en wordt voor den grond bij de uitgifte een aan zijn opbrengstvermogen geëvenredigde waarde ontvangen, dan zal, zoo het werk volgens het programma wordt uitgevoerd en de benoodigde gelden tot den rentevoet van hoogstens $3 \frac{1}{2} \mathrm{pCt}$. 's jaars worden geleend, de rekening der droogmaking, zelfs bij eene berekening van rente op rente, met een voordeelig saldo sluiten. De Staat zou dan een actief verkrijgen, dat tegen de kosten zou opwegen, en zoo de renten der voor de onderneming geleende gelden uit belastingen zouden zijn betaald, eene trouwens alleszins gewettigde vergoeding erlangen voor het offer, dat gedurende 
de uitvoering van het werk van de belastingschuldigen gevorderd zou zijn.

Of eene gemiddelde opbrengst van f $60 .-$ per hectare zal worden verkregen, zal echter, naar de Commissie niet verzuimt op te merken, in hoofdzaak beslist worden door den loop der prijzen van de landbouwvoortbrengselen. En hiervan laat zich twintig a dertig jaren te voren weinig of niets met eenige zekerheid voorspellen. De nieuwe polders zullen in de eerste tien of twintig jaren na de uitgifte der gronden, wellicht zelfs langer voor blijvend graslaud ongeschikt zijn. Aanvankelijk zal koolzaad worden verbouwd, daarna zullen waarschijnlijk tarwe, gerst, boonen, haver en klaver worden geteeld. De prijzen dezer producten zijn laag, tot een vroeger zelden gekend peil gedaald.

De tarwe, die als het voornaamste voedingsmiddel der West-Europeesche volkeren den toon voor de graanprijzen aangeeft, gold op de Engelsche markt in 1894 en 1895 niet meer dan gemiddeld $22 \mathrm{sh}$. 10 en $23 \mathrm{sh} .6$ per quarter. Om dien middenprijs in de Engelsche prijsnoteeringen terug te vinden, moet men 150 jaren teruggaan. In 1743 en 1744 was de prijs 22 sh. 1 per quarter en het geld had destijds hoogere waarde dan heden. Men zou geneigd zijn hieruit de gevolgtrekking te maken, dat voorshands het ergste wel geleden zal zijn, te meer daar na 1894 wederom eenige prijsverheffing plaats vond, die in den laatsten tijd betrekkelijk nog al aanzienlijk was. Doch al volgt op regen ook zonneschijn, het is zeer wel mogelijk dat de periode van lage prijzen lang aanhoudt en eene nieuwe daling is in den loop des tijds geenszins uitgesloten. Zelfs eene verdergaande prijsverlaging, hoezeer op den huidigen dag niet waarschijnlijk, zou vroeg of laat mogelijk kunnen zijn. In 1879 zeide Shaw Lefevre, een economist van naam, bij de opening van de vergadering van de British Association te Sheffield: Zoo ik over een zoo moeielijk en duister onderwerp eene voorspelling dorst wagen, zou ik tot de meening overhellen dat de tarwe gedurende het laatste jaar het laagste peil heeft bereikt" 1). - De middenprijs was des-

1) Journal of the Royal statistical Society, 1879 pag. 780 . 
tijds 45 sh. 5 per quarter. Sints dien tijd daalde hij tot de helft en lager.

Over de oorzaken der daling wordt verschillend geoordeeld. Oppervlakkig beschouwd ligt de verklaring voor de hand. De ontwikkeling der middelen van versnelde gemeenschap te land en te water in de laatste vijf en twintig jaren heeft de gelegenheid geopend, om in de overzeesche gewesten vruchtbare tot dusverre maagdelijke velden van onmetelijke uitgestrektheid en bij uitstek voor den tarwebouw geschikt in cultuur te brengen, en om de producten van het verre westen alsmede die van de binnenlanden van Rusland en van Britsch Indie voor betrekkelijk geringe kosten naar de havens van West-eu Midden-Europa te vervoeren. Door een rijken bodem en lage loonen of het gebruik van stoomwerktuigen van de nieuwste vinding, waardoor vooral in Amerika in groote mate menschenarbeid wordt uitgewonnen, verkeeren deze uitvoerlanden ten aanzien van de kosten van productie in gunstige voorwaarden, terwijl het nadeel van den grooten afstand van de centrale Europeesche markten door eene uitnemende organisatie van het spoorwegvervoer en den bouw van stoomschepen met groot laadvermogen allengs tot geringere afmetingen werd teruggebracht. ${ }^{1}$ ). Dat onder deze omstandigheden de Vereenigde Staten van Noord-Amerika en Rusland, tijdelijk ook Britsch Indie, en in de laatste jaren Argentinie groote hoeveelheden tarwe voor lage prijzen konden aanvoeren en de marktprijzen daarvan den terugslag ondervonden, kan niet bevreemden.

Doch velen zijn met deze verklaring niet tevreden. Menigmaal wordt de daling aan andere oorzaken toegeschreven of althans ook aan andere omstandigheden niet weinig gewicht toegekend. Zelfs worden oorzaken van zeer uiteenloopenden aard genoemd. Schoon men veelal van meening is dat de oogsten in sterkere mate dan de bevolking vermeerderden, wordt dit geenszins algemeen toegegeven, althans niet voorzooveel

1) Darid A. Wells. Recent economic changes and their effect on the production and distribution of wealth and the well being of society, pag. 166 en vv. Crawford, An inquiry into wheat prices and wheat supply in het Journal of the Royal Statistical Society van Mart 1895. 
de jaren $1880-90$ betreft $^{1}$ ), en de daling eer toegeschreven aan de invoering van hooge beschermende rechten in Frankrijk, Duitsehland, Oostenrijk en Italie, die de koopkracht dezer landen zouden verminderen, ${ }^{2}$ ) althans het debouché beperken; of wel, zooals de Duitsche agrariërs doen, geweten aan de manipulatien der beurs, die door blanco-verkoopen op termijn den prijs zou drukken $\left.{ }^{3}\right)$. En eindelijk wordt ook de toestand van

1) Eene betrouwbare statistiek der wereldoogsten vau tarwe ontbreekt. Er zijn verschillende ramingen, die onderling niet weinig verschillen.

Staat van de wereldoogsten van tarwe.

(in millioenen engelsche bushels).

Report of the Report by mr.

v. Juraschek Secretary of Peffer submitted Beerbohm's Broom-
Uebersichten agriculture to the senate evening hall's corn
der Weltwirt- van de Ver- committee on corn trade trade year
schaft. eenigde Staten agriculture and corn list.
van Noord- forestry van de Book.
Amerika. Ver. St. v, N. A.

$1870 / 80$ gem. 1944

$1878 / 87 \gg 2108$

1881 \#2232

1882

1883 » 2017

1884 》 2217

$1885 \quad$ 2041

1886 » 2063

1887 \2294

1888 \2200

- 2090

» 2109

1890

1891

1892

1893

1894

1895

2475

$\begin{array}{lll} & 2008 & \\ 2206 & 2200 & \\ 2040 & 2048 & \\ 2132 & 2128 & \\ 2160 & 2312 & \\ 2145 & 2216 & \\ 2032 & 2138 & 2174 \\ 2104 & 2254 & 2284 \\ 2170 & 2378 & 2464 \\ 2185 & 2404 & 2441 \\ & 2458 & 2512 \\ & 2506 & 2562 \\ & & 2491\end{array}$

2) C. Wilbrandt. Die agrarische Frage in de Volkswirthschaftliche Zeitfragen der Volkswirtschaftlichen Gesellschaft in Berlin.

3) Welches sind die nach deu abgeschlossenen Handels-Verträgen in Aussicht zu nehmenden Wege, um die heutige Lage des Getreidemarktes zu bessern? von Dr. Ruhland in de Zeitschrift des landwirthschaftlichen Central-Vereins der Provinz Sachsen. April 1895. Charles W. Smith. Lecture on the option, future and settlement systems of gambling in wheat, silver etc. 
het muntwezen als een der oorzaken angewezen. De daling van het zilver zou vóór de sluiting der Britsch Indische munten den uitvoer van Britsch Indie sterk hebben geprikkeld; de depreciatie van het Argentijnsche papiergeld zou in dezelfde richting werken ${ }^{1}$ ); en tengevolge van appreciatie van het goud zouden in Europa de prijzen zijn gedaald ${ }^{2}$ ).

Het bestek van dit geschrift zou zeer worden uitgebreid, indien wij de oorzaken, waaraan de daling al wordt toegeschreven, wilden onderzoeken, doch op het voorbeeld der Staatscommissie durf ik het onderzoek wel nalaten, althans zeer beperken, omdat zoo al invloeden van versehillenden aard tot de daling hebben medegewerkt, het niet twijfelachtig is dat de eerstgenoemde omstandigheid: de ontwikkeling der versnelde middelen van gemeenschap, waardoor de Europeesche markt het voordeel van de geringe productiekosten der verre gewesten deelachtig wordt, in elk geval wel de voornaamste is. Het kost thans minder moeite en tijd het graan van de binnenlanden van Argentinie naar de Engelsche havens te vervoeren, dan een eeuw geleden vaak gevorderd werd om de veldvruchten naar de locale markt van den omtrek te brengen. De stoomkracht heeft de kringen van von Thünen belangrijk uitgebreid. En waar waarsehijnlijk ons mettertijd in dit opzicht nog menige verrassing wacht, zou een onderzoek of b.v. de heffing van beschermende rechten in Frankrijk en andere landen, of de uitgifte van papiergeld in Argentinie en ook - wat mij minder aannemelijk voorkomt - de termijnhandel in granen of goudappreciatie ${ }^{3}$ ) de daling zouden hebben verscherpt, omtrent den verderen loop van den prijs

1) Bear. Agricultural progress in the Argentine Republic in the Economic Journal 1895, pag. 520. Daarentegen schrijft William Goodwin, Wheat growing in the Argentine Republic aan de papierdepreciatie weinig invloed op den prijs der tarwe toe. «Uruguay, schrijft deze, has always maintained a gold currency, and it is a curious contradiction of the idea that wheat growing in the sister Republic depends entirely upon the gold premium, to find Uruguay able to grow some 750.000 quarters of wheat for export at a profit, when prices are at their lowest point.»

2) Broomhall's Corn trade year Book 1895.

3) Zie mr. N. G. Pierson. Goudschaarschte in de Gids, 1894. 
nog weinig zekerheid geven. Met den aanwas van bevolking zal de behoefte wel stijgen, doch in weerwil van groote vermeerdering van het zielental is de prijs van bijna alle levensmiddelen min of meer gedaald, en zou hij, zoo als niet verder dalen, stabjel kunnen blijven. En al is naar beweerd wordt bij den stand van prijzen der laatste jaren geene bclangrijke uitbreiding van de tartecultuur in de Vereenigde Staten van Noord-Amerika te wachten, eene geringe prijsverheffing of vermindering van kosten schijnt voldoende om haar te weeg te brengen ${ }^{1}$ ); en met de opening van het Panamakanaal of Nicaragua-kanaal zal aan de vruchtbare Pacifickusten gelegenheid worden gegeven om haar overvloed met minder kosten dan tot dusverre naar de Europeesche markt te vervoeren en den invoer te verhoogen. De uitbreiding van het Russische spoorwegnet, wellicht ook mettertijd de opening van den Siberischen spoorweg ${ }^{2}$ ), zullen aanleiding ziju, dat Rusland's uitvoeren vermeerderen. En Argentinie, dat bijna de grootte heeft, die West en Midden Europa te zamen beslaan, bevat eene vruchtbare landstreek van 240 millioen acres, waarvan volgens de laagste schatting 150 millioen acres zich uitnemend voor den tarwebouw leenen en naauwelijks 10 millioen acres onder den ploeg zijn gebracht. Bij eene opbrengst van slechts 10 bushels per acre zou meer dan de helft van den tegeuwoordigen wereldoogst alleen op dit land, dat in een officieel orgaan der Engelsche Regeering The Journal of the Board of agriculture ${ }^{3}$ ) als een werkelijk El Dorado voor den tarweboer wordt beschreven, kunnen worden geproduceerd. I $\mathrm{k}$ wil deu Nederlandschen landbouwer niet onnoodig schrik aanjagen en voeg dus onmiddellijk hieraan toe, dat nog vele jaren zullen verloopen, alvorens deze oppervlakte in cultuur zal zijn gebracht. Ben belangrijke vermeer-

1) Thorstein. B. Velden. Food supply and the price of wheat in the Journal of political Economy. Chicago. June 1893.

$\left.{ }^{2}\right)$ In de eerste jaren wordt uit Siberie geen aanvoer van tarwe verwacht. Dr. C. Ballod. Die wirthschaftliche Bedeutung von Siberien in de Jahrbücherfür National Oekonomie und Statistik van September 1896.

$\left.{ }^{3}\right)$ September 1896, pag. 142. 
dering der immigratie en eene groote uitbreiding van het spoorwegnet zullen moeten voorafgaan, en de politieke toestand van Argentinie laat een en ander niet spoedig verwachten Doch al wordt de tarwebouw betrekkelijk slechts langzaam uitgebreid, duidelijk is het dat de tijd nog "graanoverstroomingen" van gansch anderen omvang kan brengen, dan die waarover de Hollandsche maatschappij voor landbouw thans reeds klaagt. De lage prijsstand is dus naar alle waarschijnlijkheid geen verschijnsel, waarvan, zooals een duitsch agrarier Dr. Ruhland meent, het einde reeds nadert '). Al zijn de prijzen laatstens ook gerezen en al zullen ook voortaan prijsschommelingen niet uitblijven, het algemeen prijsniveau is gedaald en kon licht, zooals vrij algemeen wordt aangenomen, nog lang laag blijven. ${ }^{2}$ )

Is de droogmaking der Zuiderzee hiermede uu veroordeeld? Een lid der Staatscommissie, die sints jaren de beweging van het wereldverkeer naauwlettend had gadegeslagen, een vrijhandelaar in hart en nieren, achtte de toekomst voor den Nederlandschen landbouw zoo onzeker, dat hij op dien groud tegen de conclusie van het verslag stemde. Waar de ondervinding van de laatste jaren leerde, dat de middelen van gemeenschap steeds verbeterd werden en daardoor de kosten van vervoer afnemen, kon, naar hij oordeelde, voortdurend van meer verwijderde landen de anvoer vermeerderen met het gevolg, dat de graanprijs verder zou dalen.

Ik wil aannemen, dat dit oordeel te pessinistisch is, den invloed, dien de aanwas van bevolking in de oude landen en vooral in de uitvoerlanden op het verbruik zal hebben, te gering schat, en niet voldoende rekening houdt met den waarschijnlijken vooruitgang der landbouwtechniek, waardoor de pachtwaarde, in weerwil van eene eventueele verdere daling van den prijs der landbouwvoortbrengselen, zou kunnen stabiel

1) Deber das nahende Ende der auswärtigen Getreidekonkurrenz. Antrittsvorlesung an der Staatswissenschaftlichen Fakultät der Universitä Zurich.

2) E. Levasseur. L'agriculture aux Etats-Unis, pag. 401. Thorstein B. Velden. 1. c. pag. 379. Prof. Dr. M. Sering. Das Sinken der Getreidepreise und die Konkurrenz des Auslandes 1894. 
blijven en zelfs rijzen. Ook thans reeds zijn de pachten geenszins in gelijke mate als de graanprijzen gedaald. ") Doch onbetwistbaar stemt de loop der prijzen bij de beoordeeling van het Zuiderzeevraagstuk tot voorzichtigheid en waarschuwt hij tegen ramingen, die thans reeds hoog mogen heeten. De gebeurtenissen der laatste jaren zijn niet bemoedigend. Zij herinneren ons, zoo wij het mochten vergeten, dat de toekomst risico's verbergt, die in rekening behooren te worden gebracht. En doen wij dit, dan schijnt vooral op den huidigen dag, nu wij na het verschijnen van het verslag van eene nieuwe daling getuigen zijn geweest, eene raming van het jaarlijksche opbrengstvermogen der Zniderzeegronden op gemiddeld $f 60$ per hectare bezwaarlijk gewettigd.

Optimisten maken hierbij waarschijnlijk de opmerking, dat, zoo de begrooting van kosten van de werken niet tegenvalt, de droogmaking en de uitgifte van de gronden binnen den gestelden tijd plaats vinden, en de benoodigde gelden tegen den rentevoet van $3 \mathrm{pCt}$. worden geleend, reeds bij eene jaarlijksche zuivere opbrengst van gemiddeld $f 45$ per hectare in de rente van het in de onderneming gestoken kapitaal zal zijn voorzien en zelfs gelijke rente zal worden genoten over het gedurende de uitvoering aan rente betaalde bedrag. En dit is juist, doch zij behooren daarbij in aanmerking te nemen, dat, daargelaten of en in hoeverre op de vervulling dezer voorwaarden mag worden gerekend, uit de omstandigheid dat de gronden geacht mogen worden een zuiver opbrengstvermogen te zullen hebben, waarvan de waarde in het algemeen kan worden bepaald, nog geenszins volgt dat de schatkist deze waarde ook zal ontvangen.

Wie dit voorbijziet, zou zich deerlijk misrekenen.

\section{VI.}

De eerste polder is droog. Hoe zal de grond thans productief worden gemaakt? Zal de Staat dien voor eigen rekening exploiteeren of wel verpachten of verkoopen? En mag hij zich

1) J. Gonrad. Landwirthschaft, in Von Schoenberg. Handbuch der politischen Oekonomie. $4^{e}$ auflage II, pag. 226. 
nu vleien alsdan dezelfde rente, hetzij opbrengst, pacht of koopsom, te zullen erlangen, als oude gronden van gelijke hoedanigheid en ligging geven?

De polder is voorshands een wildernis. Zoodra het water was geweken, zijn millioenen planten uit het slijk opgerezen, biezen en riet en wilgenboompjes en wilde andijvie, zoo hoog en dicht, dat er niet doorheen te komen is, tenzij men met beide armen de welige scheuten, die manshoogte ver te boven gaan, van een spreidt ${ }^{\mathbf{1}}$ ).

Van eene uitgifte van den grond is nog geen sprake. Zij kan niet plaats vinden, voordat de noodige wegen zijn aangelegd, de grond behoorlijk is verkaveld en zwart gemaakt, tochten en sloten zijn herschoten en de bodem in staat zal zijn steenen gebouwen te dragen. Minstens twee jaren zullen daartoe moeten verloopen. Intusschen behoeft de grond niet improductief te blijven. Veelal helpen de aannemers de ondernemers den eersten tijd door te komen. $Z_{i j}$ zijn in den regel de eerste landbouwers en zullen ook wel de pioniers der Zuiderzee zijn. Verpachting in het groot gedurende korten tijd aan enkele pachters of combinatien, die als voorloopige ondernemers op de meest eenvoudige wijze met gebruikmaking van lichte, primitieve gebouwen den bodem in cultuur brengen, zal bovendien licht noodig blijken. Volgens de Staatscommissie is dit evenwel geen bezwaar. In de maagdelijke kleigronden is zulk een groot depot van plantenvoedsel aanwezig, dat roofbouw niet alleen met gerustheid kan worden toegelaten, maar zelfs tot zekere hoogte voorgeschreven is.

Bij de begrooting van de kosten van de droogmaking wordt aangenomen, dat uit de opbrengst, die op deze wijze zal worden verkregen, de kosten van het herhaaldelijk op diepte brengen van de slooten en van hetgeen verder noodig is om het land in definitieven toestand op te leveren, kunnen worden bestreden, en dat de grond twee jaren, nadat de polder gereed zal zijn, verkoopbaar zal wezen.

De verkoop of uitgifte zal echter slechts geleidelijk kunnen geschieden. De Commissie neemt aan, evenals de Regeering in 1877

1) Zie de beschrijving van het drooggevallen Haarlemmermeer bij Gevers van Endegeest 1. c. III, pag. 94. 
deed, dat het niet wel doenlijk zal zijn, jaarlijks meer dan gemiddeld 10.000 hectaren uit te geven. Hieruit zal een niet onbelangrijk renteverlies ontstaan, waarmede in de begrooting der Commissie echter geen rekening wordt gehouden, omdat men vertrouwt, dat reeds iets vroeger met den verkoop van een gedeelte kan worden begonnen en dat de Staat de drooggemakte doch nog niet verkochte gronden voor eigen rekening productief zal kunnen maken.

Om de uitgifte te doen slagen, zal de Staat zijne eischen niet te hoog mogen stellen. Een aanbod van 10000 hectaren nieuwen grond 's jaars gedurende 19 achtereenvolgende jaren is buitengemeen groot. Daarover zijn alle deskundigen het vrij wel eens. Vreesde men niet de vermeerdering van renteverlies, dan zou er alle reden zijn de uitgifte over een langer tijdvak te verdeelen. De omvang van het aanbod en de wetenschap, dat de Staat ook in volgende jaren met gelijke gronden aan de markt zal komen, zullen de te bedingen koop- of pachtprijzen drukken. Op normale prijzen als door oudhoevigen grond van gelijken aard wordt verkregen, valt bezwaarlijk te rekenen. Te meer niet daar de drooggemaakte grond in den eersten tijd waarschijnlijk niet algemeen gewild zal zijn. De ervaring leert het dat het den eersten ondernemers ten gevolge van allerlei omstandigheden zelden voordeelig gaat, en het verblijf in de uitgestrekte polders, waarvan menig deel van de oude markten ver verwijderd zal zijn en warin de communicatiemiddelen voorshands zullen achterstaan bij die der oude provineien, zal in de eerste jaren niet aangenaam ziju ${ }^{1}$ ). 'Zij, die zich er vestigen, zullen vele geriefelijkheden, die elders worden aangetroffen, ontberen en met menig bezwaar te kampen hebben, en niet een ieder heeft de geestkracht om daarvoor niet terug te deinzen. Gunstige voorwaarden zullen dus moeten worden aangeboden om de boeren bereid te vinden zich naar de voorshands nog vrij onherbergzame vlakte der Zuiderzee te verplaatsen en hun kapitaal in de exploitatie van den nieuwen grond te wagen.

Er zijn wel is war velen in den lande, die werk zoeken

1) Jhr. Mr. I. W. H. Rutgers van Rozenburg, De Zuiderzee in Wet Vaderland van 19 Juli 1876. 
en de Zuiderzee zal hun eene welkome gelegenheid aanbieden om een middel van bestaan te erlangen. Doch al zullen dientengevolge de noodige arbeiders en ambachtslieden zich spoedig aanbieden, voor de bebouwing van den grond worden kennis en kapitaal vereischt. De $\mathbf{1 9 0 . 0 0 0 ~ h e c t a r e n ~ k u n n e n ~ n i e t ~ a a n ~ a r b e i - ~}$ ders worden uitgegeven. Ondernemers zullen niet gemist kunnen worden, en al pachten zij slechts den grond, zij behoeven althans een betrekkelijk niet gering bedrijfskapitaal. Voorwaarde van welslagen van het programma der droogmaking is dus, dat, zoodra de gronden voor definitieve uitgifte gereed zijn, ten minste binnen korten tijd daarna, een voldoend aantal landbouwers, voorzien van het vereischte bedrijfskapitaal, bereid zullen zijn de exploitatie te ondernemen en eene behoorlijke vergoeding voor den afstand van den eigendom of het gebruik van den grond te geven.

Hoe hiertoe nu te geraken?

$\mathrm{Bij}$ alle droogmakingen werd de bodem, voorzooverre die niet door de ondernemers zelve werd in cultuur gebracht, eenvoudig aan den meest biedende verkocht, zoodra hij voor bebouwing geschikt was. De koopers stichtten de noodige woningen, stallen en schuren, die voor het bedrijf noodig waren, en ondernamen zelve de exploitatie of verpachtten de door hen gevormde boerenplaatsen.

De Commissie wenseht dien weg niet te volgen.

Niet alleen financiëele redenen, doch vooral overwégingen van socinalpolitieken aard nopen, nanr de Commissie betnogt, om de gronden bij voorkeur niet te verkoopen, vooral niet te veilen, maar zoo mogelijk op audere wijze uit te geven. Een voorstel om den grond aan den hoogst biedende te verkoopen, zou naar zij schrijft, "niet gedaan kunnen worden zonder voorbij te zien en te miskennen alles, wat in den laatsten tijd is gedacht en geschreven over de verhouding tusschen eigenaren en gebruikers van den bodem, over de gebreken, die ons tegenwoordig pachtstelsel aankleven en over de middelen, die kunnen worden angewend om een zooveel mogelijk welvarenden en ontwikkelden landbouwstand in het leven te roepen." 'Zij wil daarom ook den nieuw aangewonnen grond niet als staatsdomein in pacht uitgeven, wandoor de Staat als landheer zou optreden. Zoo mogelijk komt deze wijze van ECoN. 1897. 
uitgifte haar nog minder raadzaam voor. Iedere regeling, waarbij toepassing van het gewone pachtstelsel zou noodig zijn, behoort haars inziens, zoo het kan, te worden vermeden. Om den afzet van den grond te verzekeren, wil zij verkoop en desnoods ook verpachting niet volstrekt uitsluiten, maar de nitgifte dient zooveel doenlijk te geschieden op zoodanige wijze, dat de grond kome in het bezit van den gebruiker. Het streven moet zijn, dat in de nieuwe polders zich een eigengeërfde boerenstand vestige en dat deze daar gevestigd blijve. Dit doel is, naar de Commisie oordeelt, niet te bereiken dan door den grond in erfpacht of beklemming uit te geven of, voorzooverre dit niet mocht doenlijk blijken, op grondrente te verkoopen of wel, zoo de grond in vollen en vrijen eigendom zal worden overgedragen, de verkoopvoorwaarden zoodanig in te richten, dat hij bij de uitgifte zoo min mogelijk in handen van uitwonende ejgenaren komt.

De hoofdgedachte, die aan deze beschouwing ten grondslag ligt, ' is ongetwijfeld juist. Onbetwistbaar heeft de Staat bij de uitgifte van den grond op andere belangen te letten dan de particuliere oudernemer in den regel doet. Deze gaat alleen met zijn eigen belang te rade en verkoopt of verpacht den grond, naarmate hij van het een of van het andere voor zich zelven het meeste voordeel verwacht. Op het belang van den boer, die het land in den loop des tijds zal gebruiken, geeft hij weinig of geen acht. De Staat mag niet aldus te werk gaan. Hij heeft hoogere belangen en sociale plichten, die beiden hem den eisch stellen zooveel doenlijk zorg te dragen, dat op den nieuwen bodem zich een gezonde agrarische toestand ontwikkele. Het doel der onderneming wordt niet bereikt met land aan te winnen, waarvan de verkoop voor de schatkist voordeel laat. De droogmaking beoogt de nationale welvaart te verhoogen, en dit vindt niet plaats, wanneer het aan de bevolking, die zich in de Zuiderzee provincie zal vestigen, niet wel zal gaan; wanneer zij daar slechts een kommervol bestaan zal vinden, zoodat zij bij den minsten tegenspoed, die licht kan intreden, armlastig zou worden; wanneer in het nieuwe gewest een toestand geboren zou worden als in Friesland reeds wordt aangetroffen. En om dit te roorkomen is het noodzakelijk de voorwaarden, 
waaronder de grond wordt afgestaan, zoo goed mogelijk te regelen.

Het moeielijke probleem, dat de Staat na de droogmaking zal moeten oplossen, wordt hierdoor echter hoogst ingewikkeld. De heterogene belangen van de schatkist en van de kolonisten, belangen, die ieder voor zich reeds niet weinig zorg eischen, zullen zoo moeten worden waargenomen, dat de eene niet aan de andere worden ten offer gebracht. Of het bij eene regeling der uitgifte als door de Commissie allereerst wordt beoogd, doenlijk zal zijn groote schade voor de schatkist te vermijden, of zelfs zonder op het belang van de schatkist sterk acht te slaan, de uitgestrekte provincie der Zuiderzee behoorlijk te koloniseeren, is voor twijfel vatbaar en vordert althans zeer nauwgezette overweging.

\section{VII.}

In het verslag der Staatscommissie straalt groote voorliefde door voor eene uitgifte in erfpacht of beklemming en een verkoop op grondrente.

De laatste wijze van uitgifte zou op deu duur weinig of niet van een eenvoudigen verkoop verschillen, tenzij de bepaling van het Burgerlijk wetboek, dat de grondrente altijd, althans na 30 jaren afkoopbaar is, verviel. Economisch zouden de drie instituten dan vrij wel overeenkomen, zoodat wij ons kunnen bepalen tot het onderzoek of eene uitgifte in erfpacht tot het door de Commissie beoogde doel zal leiden.

Erfpacht is voor eene geringer som te verkrijgen dan eigendom, en kan dus een geschikt middel zijn orn onder de landbouwers het aantal gegadigden voor den Zuiderzeegrond te vermeerderen, en vooral om den "kleinen layden" gelegenheid te geven een deel in gebruik te erlangen. Zij verzekert ook, wanneer zij naar het denkbeeld der Commissie eeuwigdurend zal zijn, aan den erfpachter of zijn rechtverkrijgende al het voordeel, dat goede zorg of aangebrachte verbetering van den grond zal afwerpen, en zal mitsdien eer dan pacht tot duurzame verbetering van de productiviteit van den bodem aansporen. In zooverre is zij alleszins geeigend om een welvarende eigengeërfde bevolking in de Zuiderzee te verkrijgen.

Het oude rechtsinstituut, dat in den loop der eeuwen bijna in onbruik geraakte, in den laatsten tijd hoofdzakelijk 
slechts bij de uitgifte van ongecultiveerden grond wordt toegepast, en bij onze oostelijke buren door den wetgever in 1850 zelfs in den ban werd gedaan, komt allengs wederom in aanzien. Velen beschouwen het als het middel, dat bij de oplossing van het agrarisch vraagstuk grooten dienst kan bewijzen, den landbouwer tegen de macht van den renteheffer of den kapitalist zal beschermen. ') En de pruisische wetgever liet in 1891 in de plaats vau het verdreven instituut het

1) Thaer Rationelle Landwirthschaft $\S 131$, had reeds voorlang erfpacht genoemd: «die erste Basis, worauf der allgemeine Wohlstand und der höhere Betrieb der Ackerbaugewerks gegründet werden kann.»

Emile de Laveleye. De la propriété et de ses fornes primitives, $4^{e}$ ed., pag. 517 noemt haar «une forme ancienne de la propriété, que les législateurs et les économistes ne doivent point négliger d'examiner, parcequ'elle peut apporter un élément de conciliation dans le débat engagé partout entre celui qui met la terre en valeur et celui, qui touche la rente.... Le beklemrecht, assurant aux cultivateurs la pleine jouissance de toute auginentation du produit est donc le plus énergique des stimulants. Il encourage l'esprit du perfertionnement, que le bail à court terme met à l'amende».

Volgens Adolf Wagner (Finanzwissenschaft I, $\$ 230$ ) is zij xein wichtiger Massregel gesuuder Socialpolitik. Denn sie kann zur Erhaltung oder Gründung eines tüchtigen Bauerstands dienen und auch kleinen Leuten (Arbeitern) zu Grundbesitz verhelfen ohne die Gefahr sie vom Grossgrundbesitz und Kapital bald wieder verdrängt zu sehen.

Buchenberger. Agrarwesen und Agrarpolitik ( $3^{e}$ deel van Adolf Wagner Lehr- und Handbuch der politischen Oekonomie) 1 , pag. 204, is in het algemeen ran de toekomst der erfpacht niet overtuigd, doch sluit zich, voor zooveel de colonisatie van groote domeinen betreft, bij de vorigen aan, en voegt daarbij eene mededeeling, waarvan het slot voorzeker nieuw is. «Desshalb ist schon in vorigen Jahrhundert bei Zerschlagung von Domänengütern zu Besiedelungszwecken die Vererbpachtung mit guten Gründen zur Anwendung gelangt, haben gewichtige Stimmen für diese Bezitesform bei der Wiederaufnahme der inneren Colonisation in jüngerer Zeit (in den dünnbevölkerten Latifundienbezirken des preussischen Nordens und Nordostens) sich ausgesprochen, hat man bei der Neubegründung von Bauerustellen in Mecklenburg im Bereich des Domaniums thatsächlich für die Erbpacht als ausschliessliche Besitsform sich entschlossen und bei der Besiedelung durch Trockenerlegung der Zuidersee gewonnenen Polders ebenfalls diesen Weg betreten.» 
oconomisch nawverwante Renteg ut toe, waarbij de eigendom wel op den verkrijger overgaat, doch onder den last van eene grondrente, die zoo partijen het overeenkomen, zelfs onopzegbaar en onaflosbaar zal zijn.

Met al haar goede eigenschappen is de erfpacht als alle nenschelijke instellingen echter geenszins volmaakt. Een bezwaar is dat het goed zonder toestemming van den eigenaar niet kan worden gesplitst, hetgeen bij verkoop of ruil of boedelscheiding hinderlijk kan wezen. Zij geeft ook geen volstrekte zekerheid, dat het goed niet mettertijd in handen van kapitalisten komt, die de erfpacht eenvoudig als een middel van geldbelegging gebruiken, waarvan zij door verpachting rente trekken. In Groningen klaagt men reeds dat dit met een aantal beklemde hoeven plaats vindt ${ }^{1}$ ). En eindelijk zal eene uitgifte in erfpacht niet minder dan verkoop voor de schatkist nadeelig kunuen zijn. Een groot aanbod zal op den te bedingen canon en op de vergoeding, die, naar de Commissie voorstelt, voor de verwerving van het recht zal moeten worden betaald, van ougunstigen invloed zijn, en de Stant zou dientengevolge een grooter of kleiner deel vau de grondrente, die het goed reeds bij de uitgifte afwerpt, derven.

Door eene regeling van het erfpachtsrecht deze bezwaren op te heffen, zal moeielijk gaan. De Staat zou licht van den regen in den drop vallen. Bepalingen, dat het goed niet zal mogen worden verpacht dan met goedvinden vau het domeinbestuur, of dat de canon op gezette tijden zal worden herzien, zouden de erfpacht zeer weinig begeerlijk maken. Vooral de latste, indertijd in overweging gegeven door den Staatsraad Moltzer ${ }^{2}$ ), ten einde de gemeenschap het voordeel van eene eventueele stijging van de grondrente te doen genieten, is voor den erfpachter nauwelijks aanneembaar. Iu de onzekerheid, welke pachtsom hij mettertijd zal moeten betalen zal hij kwalijk geneigd zijn on voor het erlangen van het erfpachtsrecht een koopprijs ten bedrage van een vierde vau de geschatte waarde te betalen, als de Commissie voorstelt van

1) Adviezen der Landbouw-commissie, pag. 150.

2) De Zuiderzee als proefreld voor onzen agrarischen Wetgever. De Gids, April 1893. 
hem te eischen, en inderdaad ook gevorderd behoort te worden als zekerheid dat de erfpachter in dagen van malaise het land, na het verwaarloosd te hebben, niet abandonneert. Zelfs eene bepaling dat de pachtsom, die in dit geval drie vierde van de netto huurwaarde zou bedragen, zoo noodig in den loop des tijds door een agrarischen rechter zal worden herzien en op nieuw vastgesteld, zal hem niet gerust stellen. Ook de rechter kan ten aanzien van de schatting van de waarde dwalen, en een verstandig ondernemer zal niet buiten noodzakelijkheid verplichtingen aangaan, waarvan het bedrag door een derde zal worden bepaald. De uitkomsten van het landbouwbedrijf zijn reeds wisselvallig genoeg. Er is werkelijk alle reden, om de onzekerheid niet te vermeerderen.

Zelfs wanneer de canon onveranderlijk zou zijn, is het nog verre van zeker of erfpacht wel in den smaak van onze landbouwers zal vallen, wanneer de canon betrekkelijk hoog zal zijn, en voor de verwerving van het recht eene som ten bedrage van een vierde van de koopwaarde zal moeten worden betaald. Dat erfpachten, waarvan de canon vaak nominaal, althans laag is, gewild zijn, bewijst nog niet, dat zij dit ook zullen zijn, waar de canon bij daling van de huurwaarde, van deze weinig zou verschillen, ja haar zelfs te kunnen te boven gaan. In de Zuiderzee Commissie vond de erfpacht warme voorstanders, doch de geschiedenis van het instituut geeft reden tot twijfel. De erfpachter heeft meestal gestreefd den vollen en vrijen eigendom te verkrijgen, en meestal is hij daarin geslaagd. De schuldenlast, die nimmer gedelgd wordt, is velen niet aangenaam, reeds daarom niet omdat zij ter verzekering van de rechten van den blooten eigenaar den landbonwer in zijne vrijheid om het goed naar welgevallen te gebruiken, zij het ook nog zoo weinig, beperkt ${ }^{1}$ ). Zelfs in Groningen, waar het beklemrecht reeds lang inheemsch is, en naar algemeen getuigd wordt, weldadig heeft gewerkt, wenscht de beklemde meijer, hoezeer het beklemrecht in den regel gering is, de beroegdheid het recht af te koopen. Eenige jaren geleden werd reeds door de Provinciale Staten tot de Regeering het verzoek gericht eene daartoe strekkende bepaling in het Burgerlijk Wetboek op te nemen. Waar geld op hypo-

1) W. Roscher. System der Volkswirthschaft II, § 70 . 
theek gemakkelijk is te verkrijgen, de rentestand is gedaald en de hoop op eene verdere daling hiermede is opgewekt, kon het licht bij de uitgifte van de Zuiderzeegronden blijken, dat erfpacht slechts bij uitzondering bruikbaar is, doch allerminst een geschikt middel is om èn de groote uitgestrektheid spoedig te koloniseeren èn voor de schatkist eene rechtmatige vergoeding voor den afstand van het gebruiksrecht te erlangen. Wie in staat is een vierde van de waarde te betalen, zal eigenaar willen worden, als landbouwer en als geldopnemer onafhankelijk willen zijn. Vooral groote landbouwondernemers, die niet gemist zullen kunnen worden, zullen niet geneigd zijn grond in erfpacht te nemen ').

\section{VIII.}

Zou Domeinverpachting, door de Commissie zoo streng veroordeeld, bij behoorlijke regeling niet in vele opzichten aan den gestelden eisch kunnen voldoen? Ik heb te dien aanzien ook getwijfeld, doch nadere overweging bracht in mijne zienswijze eenige verandering.

Volstrekte zekerheid, dat geene ongewenschte verhoudingen tusschen landheer en landgebruiker zullen ontstaan, is niet te verkrijgen, tenzij de Staat de beschikking over den grond aan zich behoudt en geen zakelijk recht, hetzij dan eigendom of erfpacht, verleent, dat aan den verkrijger de macht overdraagt op van een sociaalpolitisch standpunt niet goed te keuren voorwaarden het gebruik aan derden af te staan. Alleen dan, wnnneer de Staat slechts een persoonlijk gebruiksrecht geeft, m. a. w. alleen bij verpachting, zal hij het in zijne hand hebben en houden de voorwaarden, waaronder de landbouwer het gebruiksrecht zal uitoefenen, op alleszins billijke wijze te regelen en zoo noodig in den loop des tijds daarin wijziging te brengen. En verpachting heeft daarbij het voordeel, dat voor de verwerving van het gebruiksrecht geen kapitaal wordt vereischt, en dus al het voor het landbouwbedrijf in de nieuwe polders beschikbare kapitaal voor de

1) Zie Mr. S. van Houten. Het recht van beklemming uit een staathuishoudkundig oogpunt beschouwd in de $\mathrm{Ni}$ eu we bij dragen voor Rechtsgeleerdheid en Wetgeving. 1861, pag. 836. 
exploitatie gebezigd zal kuunen worden; en last not least dat de Staat, al moet hij zich, naar waarschijnlijk is, aanvankelijk ook met een betrekkelijk geringe pacht vergenoegen, niet voor altijd afstand doet van zijne aanspraak op volle vergoeding der grondrente, die in de nieuwe polders eerst geleidelijk hare normale hoogte zal bereiken.

Het pachtstelsel heeft het in den laatsten tijd hier te lande hard te verantwoorden. Er wordt en niet ten onrechte niet weinig kwaad van gezegd. De vermeerdering van het productief vermogen van den grond, zelfs het onverminderd behoud daarvan bevordert het niet. Er is steeds gevaar dat de pachter, wiens belang medebrengt in den dikwerf korten duur van zijn gebruiksrecht het grootst mogelijke voordeel van den grond te trekken, zich weinig bekommeren zal of de opbrengst in de toekornst daardoor ook mocht verminderen. En bij de hoog opgedreven huren en lage prijzen der landbouwvoortbrengselen is het gevaar grooter dan ooit, dat hij allereerst trachten zal, zij het ook ten koste ${ }^{-}$van den grond, zich zelven tegen verlies te vrijwaren. Onder een oordeelkundig domeinbestuur kan echter de werking van het stelsel in menig opzicht verbeterd worden, zoo dat de rechtmatige grieven voor een. groot deel vervallen 1). Indien het domein na ingewonnen advies van een pachtcommissie de huur op een billijk cijfer vaststelt, zonder te vragen of wel het uiterste is bereikt, wat bij de scherpe mededinging der landbouwers wellicht kon worden verkregen, en geen al te beperkende bepalingen omtrent vruchtopvolging makkte, maar goed toezag bij de keuze van den pachter, die beteren waarborg in zijn persoon kan geven dan

1) Van de Pruisische domeinverpachting schrijtt Meitzen Boden Preussen's III, 419. «Sie haben eine wichtige Rolle in der Entwickelung der vaterländischen Landwirthschaft vertreten. Sie haben bis auf die neuste Zeit zu den besonders intelligent betriebenen Wirthschaften gehört und einem grossen Theile ihrer Leiter bei ausserordentlich grossen Aufwendungen und Verbesserungen gleichwohl in der Regel erhebliche Reichthümer geschaffen". Volgens Wagner, Lehr und Handbuch der politischen Oekonomie, $3^{\circ}$ ed., Deel 2, pag. 442 wordt dit oordeel ook thans nog algemeen gedeeld. 
een uitvoerig pachtcontract, en het bedrijf naging; wanneer voorts - hetgeen alles doenlijk is - als regel werd aangenomen, dat de pachter, die het land goed verzorgt, bij afloop van de huur op verlenging daarvau aanspraak zal hebben, zonder dat verbeteringen door hem angebracht tot verhooging van den huurprijs zullen leiden; dan zou er wel geen groot bezwaar zijn een deel der Zuiderzeegronden in pacht wit te geven. Onder al hetgeen over het pachtstelsel gezegd en geschreven is, mag niet worden voorbij gezien wat de Landbouwcommissie schreef: dat de huurboer op zich zelf ongetwijfeld evenzeer recht van hestaan heeft als de landbouwer-eigenaar, en dat in normale verhoudingen, wanneer vaste gewoonten den bekwamen huurder continuatie van huur verzekeren, de huur volstrekt geen nadeel is, integendeel het middel, waardoor energieke, maar onbemiddelde boerenzoons vooruit kunnen komen of althans een bestaan kunnen vinden in het voorvaderlijk bedrijf." ${ }^{-1}$ )

Hoe dit echter zij, men kan zich moeielijk vleien, dat het gelukken zal in 19 jaren alle perceelen der Zuiderzee op aanneembare voorwaarden te verkoopen of in erfpacht uit te geven. De Staat zal, of hij wil of niet, gedwongen worden een deel der gronden, ook na het tijdperk der voorloopige exploitatie, te blijven verpachten. Het gevaar, dat hij dientengevolge in de noodzakelijkheid kon komen op deu duur zelf te exploiteeren - een gevaar, waarop de Staatscommissie wijst - acht ik niet groot. Mocht een enkele maal eene hofstede onverhuurd blijven - veel behoeft het niet voor te komen - dan zal wel raad zijn te schaffen; maar waar is het, dat het uit een politiek oogpunt niet gewenscht is, dat de bevolking van een gausch gewest voor een groot deel uit domeinpachters bestaat. Het belang der pachters kan licht met dat van het domeinbestuur in botsing geraken. En daarbij zou de schatkist nog in den bouw van woningen en schuren moeten voorzien, waarmede, naar wij zagen, de niet geringe uitgaaf van $f$ 200. - per hectare gemoeid zou zijn. Doch wie de droogmaking wil, zal deze bezwaren, wier omvang en duur moeielijk vast te stellen zijn,

1) Oitkomsten van het onderzoek naar den toestand van den landbouw in Nederland, $4^{\circ}$ deel, pag. 97. Verzameling van adviezen der landbouwcommissie, pag. 144. 
voor lief moeten nemen. Hij zal reeds tevreden moeten zijn, wanneer het spoedig gelukt een voldoend aantal zaakkundige pachters met het noodige bedrijfskapitaal op behoorlijke voorwaarden te vinden.

IX.

Ook verkoop zal bezwaarlijk uitgesloten kunnen blijven, en voor eene intensieve bebouwing van den grond en niet het minst voor de ontwikkeling van de bevolking van het nieuwe gewest kan het niet anders dan voordeelig zijn, dat geen gering deel van den bodem in handen komt van welgestelde landgebruikers, die als eigenaren alle belang hebben om geen middel onbeproefd te laten, dat de productiviteit van den grond kan bewaren en verhoogen, en hunne medeingelanden door hun voorbeeld daartoe op te wekken.

Ik erken het bezwaar, dat - al zou de Staat den grond slechts verkoopen aan landbouwers, die zelven het land zullen gebruiken, en de koopprijs in annuiteiten betaalbaar worden gesteld, opdat landaankoop door kapitalisten niet als middel van geldbelegging zou worden gebezigd - de bodem niettemin mettertijd in handen kan komen van uitwonende en inwonende eigenaren, - de laatsten zijn somwijlen de ergsten — die den grond verpachten; en ik weet geen afdoend niddel om dit bezwaar te ondervangen. Eene bepaling, waarbij den kooper en zijnen opvolgers het recht werd ontzegd den grond te verhuren, tenzij mat toestemming van het domeinbestuur, zou het aantal gegadigden voor den grond zeer verininderen en op den te bedingen koopprijs niet weinig nadeelig werken. Wellicht kon eene herziening van de wettelijke regeling van het pachtcontract - de droogmaking laat den wetgever daartoe voldoenden tijd - de nadeelen van de pacht opheffen of verminderen, doch mag men de deskundigen gelooven, dan doet men wel de verwachting te dien aanzien niet te hoog te spannen. Schreef de Landbouwcommissie reeds in haar advies betreffende het pachtcontract en het gebruik van den grond, dat "van wettelijke maatregelen in het algemeen tot verbetering van de thans geldende rechtsverhoudingen ten aanzien van het gebruik van den grond weinig heil te wachten is", de jongste vergadering van 
de Vereeniging voor de Staathuishoudkunde en de $\mathbf{S}$ tatistiek en de aan har uitgebrachte praeadviezen hebben deze uitspraak vrij wel bevestigd. Ook het middel, door den heer Moltzer aan de hand gedaan, ') die aau den pachter het zoogenaamde beneficium competentiae wil verleenen, getuigt meer van de edele bedoelingen van den geneesheer dan dat het baat zal aanbrengen. Het kon integendeel eer werken als een premie op onbekwaamheid, onvoorzichtigheid en gebrek aan jiver, en eene bron van twist tusschen landheer en pachter worden.

Zou verkoop bij de uitgifte der Zuiderzee-velden evenwel uitgesloten moeten worden, wijl verpachting op deze wijze mogelijk werd, men zou alsdan allicht beter doen de visschen in het bezit van het water maar niet te storen. Want vroeg of laat zal het wel blijken dat aan de overige wijzen van uitgifte niet minder bezwaren, zij het ook van anderen aard, zijn verbonden, zoodat verkoop van groote uitgestrektheden noodig of wenschelijk wordt.

Intusschen men doet verkeerd, zooals in den laatsten tijd vaak geschiedt, alleen het oog te vestigen op de keerzijde van het pachtstelsel. Behalve dat het den landbouwer, die zich in de nieuwe provincie wil vestigen, gelegenheid laat het gansche hem ten dienste staande kapitaal voor de exploitatie van den grond te bezigen, zal het ook uit de steden kapitaal naar de Zuiderzee brengen, en in kwade tijden, die niet zullen uitblijven, den landgebruiker althans voor een deel ontheffeu van het risico van het bedrijf.

Waren de eigengeerfden in den regel welgezeten burgers, en mocht men zich vleien dat zij dit ook zouden blijven, dan was er nog reden om zoo mogelijk geene pachters naast hen toe te laten, maar de eigengeerfden lijden vaak aan een wel is waar andere, doch niet minder ernstige $\mathrm{kwaal}$. Hun eigendom is niet zelden belast. Bij den aankoop of bij de boedelscheiding, waarbij het vaderlijk erfdeel werd toebedeeld, is het goed veelal met schuld bezwaard, en velen gaan daaronder zoozeer gebukt, dat zij in jaren van misgewas of lage prijzen buiten machte zijn het land behoorlijk te verzorgen. Hun toestand is in zoodanig geval ongunstiger dan die van menig pachter, en

1) Landbouw en kapitaalbelegging. 
de bodem lijdt niet licht meer schade dan van een eigenaar, die oin zelf staande te blijven hem verwaarloost of het uiterste van hem vergt.

Wel verre van een nadeel achtte de Landbouwcommissie het "voor den landbouw een geluk, wanneer de kapitalisten een deel van den grond in handen hebben. Het is bevorderlijk, dus schreef zij, aan eene geregelde ontwikkeling, indien in onguustige tijden dat bezit zich kan uitbreiden om weder door de werking van natuurlijke oorzakeu te worden ingekrompen, wanneer het den landbouwer goed gaat. Door aankoop van grond geven de kapitalisten, vooral in een tijdvak van gedruktheil, den landbouw een niet genoeg gewaardeerden steun" ${ }^{1}$ ).

Gedurende 19 jaren jaarlijks groote uitgestrektheden te gelde te maken, zal echter, wil men zich ten slotte niet met spotprijzen tevreden stellen, vooral in weinig gunstige tijden een moeilijk werk zijn. En niet minder moeilijk valt het zich thans reeds een eenigszins nauwkeurig denkbeeld te maken van de prijzen, die alsdan bedongen zullen worden.

$\mathrm{Bij}$ het wetsontwerp tot droogmaking der Zuiderzee, in 1876 door de regeering ingediend, werd de opbrengst op gemiddeld f 1000.- per hectare geschat. Eene mats chap tot droogmaking van het zuidelijk deel der Zuiderzee had kort te voren concessie tot het indijken van dit deel met eene staatssubsidie van $f 43.700 .000$ angevraagd. Door die inpoldering zon een oppervlakte van 176.000 hectaren verkoopbaar land worden verkregen.

Naar aanleiding daarvan schreef de heer Rutgers van Rozenburg in het reeds vermeldde artikel in $\mathrm{Het} \mathrm{V}$ ade $\mathrm{l}$ land. "De Staat, als hij liever dan die premie of $f 44$ millioen te geven, zelf de droogmaking onderneemt. welke naar de raming eener Staatscommissie moet kosten $f 123.500 .000$ of met het renteverlies gedurende de constructie $f 179$ inillioen ${ }^{2}$ ), dient aan te nemen, dat de verkoop van gronden $f 135$ millioen of per hectare

1) Adviezen der Landbouwcommissie, pag. 144.

2) Met inbegrip der kosten wegens verlies van renten en rente van rente ad $5 \mathrm{pCt}$., was het totaal der kosten geraamd op $\mathrm{f} 184.107 .000$, dus iets hooger dan door den heer Rutgers van Rozenburg wordt aangenomen. 
f 766.50 opleveren kan. Naar het mij voorkomt, maakt men zich, dit of iets wat er naar gelijkt, zich voorspiegelende, een hersenschim, en ten spijt van de kans dat men mij bespotte of weder uit de hoogte antwoordde met de vraag of men dan in Nederland in deze eeuw met best land behoeft verlegen te zijn, meen ik dat men zelfs op de helft van $f 135$ millioen als opbrengst der te verkoopen gronden niet rekenen mag.... Werden dus 16 jaren achtereen minstens 11.000 hectaren jaarlijks aangeboden, het aanbod zou niet alleen spoedig de vraag overtreffen, maar nemers zouden weldra ontbreken. De gronden, het dichtst bij den voormaligen oever zouden aardig wat opbrengen, die verder afgelegen allengs minder en voor die meer naar het midden zouden binnen kort kwalijk koopers te vinden zijn."

Dit oordeel is merkwaardig, omdat het uitgesproken werd in den gouden tijd, toen land het hoogst werd gewaardeerd, door een man, ervaren in inpolderen, die als directeur der A msterdamsche Kanalmatschappij kort te voren de IJpolders voor hooge prijzen had te gelde gemaakt ') Hierrnede vergeleken schijnt zijne schatting erg pessinistisch; doch. al is, wat ik aannemen wil, zijne schildering te donker, wie zich voor teleurstellingen wil vrijwaren, moet den invloed van een groot en langdurig aanbod niet gering achten. De lage prijzen zullen wel is waar kapitalisten uit de steden lokken, waardoor een vergaande daling kon worden tegengehouden, doch ook zij zullen rekening houden met de annhoudende werking van komende veilingen en slechts bereid zijn kapilaal in de Zuiderzee te beleggen, wanneer zij den grond goed en gemakkelijk kunnen verhuren. En zoo de Staat ook op deze en op andere wijze grond uitgeeft, konden zij licht moeite hebben goede pachters te vinden; terwijl zoo de Stant dit niet zou doen, het nadeel van het groote aanbod

I) In polder I (Wijkermeer) werden verkocht 1000 hectaren tegen gemiddeld ruim $\mathrm{f} 2000$ per hectare;

in polder II 1200 hectaren tegen gemiddeld f 2046 per hectare;

in polder III 1100 hectaren tegen gemiddeld $f 2868$ per hectare;

in polder $V$ en VI, waar zich een strook veen bevindt, 334 hectaren tegen $f 1800$ per hectare. 
zich ongetwijfeld sterk zou doen gevoelen. Genoeg om te bewijzen, dat de uitgifte der gronden een buitengewoon beleid zal vorderen.

De IJpolders - zij zijn slechts 5.500 hectaren groot werden bij kleine gedeelten van 500 tot 600 hectaren met tusschenpoozen van een half jaar geveild. Bij de Zuiderzee zal men dien weg niet kunnen volgen. De Haarlemmermeer, die evenwel slechts een elfde van de oppervlakte heeft, welke de Zuiderzeepolders zullen beslaan, werd in twee jaren verkocht, maar de voor de Haarlemmermeer bedongen prijzen doen vermoeden, dat de snel op elkaar gevolgd zijnde veilingen ongunstig op den prijs hebben gewerkt ${ }^{1}$ ), en de teleurstelling, door eenige koopers ondervonden, was van dien aard dat het waarschijnlijk niet raadzaam zou zijn geweest spoedig verdere veilingen te houden.

$\mathrm{X}$.

Zelfs al wordt, zooals de Commissie ten slotte voorstelt en ongetwijfeld aanbeveling verdient, geene wijze van uitgifte. uitgesloten, die den afzet kan bevorderen, ook dan nog kon het licht ondoenlijk blijken jaarlijks 10.000 hectaren op aanneembare voorwaarden uittegeven. In dit geval zou de Staat verplicht zijn een grooter of geringer deel der drooggemaakte gronden voorloopig zelf te exploiteeren.

1) Staat van verkoopprijzen van het Haarlemmermeer.

16 Aug. 1853 784 H.A. voor gemiddeld f 733 per H.A.

\begin{tabular}{|c|c|c|c|c|c|c|c|}
\hline 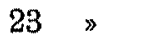 & 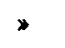 & 1273 & $»$ & $»$ & 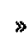 & -583 & » \\
\hline 28 Oct. & * & 514 & » & 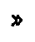 & $»$ & -680 & » \\
\hline 9 Nor. & $\gg$ & 583 & $»$ & » & $»$ & -420 & » \\
\hline 20 Febr. & 1854 & 3263 & \# & $\#$ & " & -416 & » \\
\hline $8 \mathrm{Mei}$ & $\varnothing$ & 3510 & 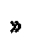 & $»$ & " & -386 & \\
\hline 27 Sept. & $»$ & 1432 & , & $»$ & » & -530 & \\
\hline 99 Nov. & » & 1269 & $"$ & 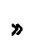 & , & -459 & \\
\hline $3 \mathrm{Mei}$ & * & 1201 & » & » & » & » 411 & \\
\hline 15 Juni & $\triangleright$ & 1498 & $"$ & $»$ & $\geqslant$ & * 499 & * \\
\hline $0 \gg$ & & 1507 & 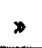 & 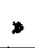 & 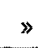 & $\rightarrow 448$ & » \\
\hline
\end{tabular}

Totaal 16842 H.A. voor gemiddeld f 473 per H.A.

Zie ook het Verslag der Zuiderzee-Commissie, pag. 151. 
De Staatscommissie ziet hierin weinig bezwaar. Op de nieuw drooggemaakte gronden, waarin een buitengewoon groot depot van plantenvoedsel is neergelegd, is in den eersten tijd bemesting niet noodig en zelfs niet gewenscht. De Staat zou dus met een betrekkelijk eenvoudige cultuur kunnen volstaan, en hiertoe acht de Commissie het domeinbestuur alleszins bekwaam. "Met degelijke deskundige mannen aan het hoofd, dus schrijft zij, wordt in naburige rijken met niet geringe voordeelen door gemeenten en gewesten en den Staat zelven de warlijk ook niet gemakkelijke boschcultuur gedreven. Zeer stellig zal onder deskuudige leiding de bebouwing der nieuwe Zuiderzeegronden tijdelijk door den Staat kunnen worden ondernomen, wanneer het blijken zal dat eene langzame geleidelijke uitgifte van den nieuwen bodem gewenscht of noodig is."

Het is te hopen dat, mocht staatsexploitatie noodzakelijk blijken, het domeinbestuur aan deze gunstige verwachtingen zal beantwoorden. In Pruisen, waar zoodanige exploitatie van domeinen niet ongebruikelijk was, is sints 1810 bepaald, dat zij, behalve bij boschen, op iedere wijze vermeden moet worden en slechts in geval van uiterste noodzakelijkheid met bijzondere machtiging van den koning geoorloofd zal zijn. Zoozeer had de ervaring bewezen, dat de Staat de minst geschikte landbouwer is ${ }^{1}$ ). De bruto-opbrengst was gering, omdat de ambtenaren de noodige vrijheid van beweging misten, om van alle omstandigheden partij te trekken, en de kosten waren hoog, omdat de staatsadministratie niet zuinig is en de onoutbeerlijke contrôle van arbeiders en ondergeschikte ambtenaren geene geringe uitgaven na zich sleept. En de landbouw is een bedrijf, dat zelfs bij groote vlijt en zuinigheid slechts matige winsten afwerpt.

Ik vrees, dat de uitkomst bij ons niet beter zou zijn, zelfs al werd de exploitatie aan een afzonderlijke afdeeling van een der departementen van algemeen bestuur opgedragen. Staatsadministratie met de daaraan onafscheidelijk verbonden contrôle is steeds omslachtig. En al zal in den aanvang de

1) Rau. Grundsätze der Finanzwissenschaft, III $\$ 104 .-$ Ad.

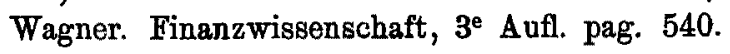


cultuur betrekkelijk eenvoudig zijn, dit voordeel vermindert en houdt ten slotte op, wanneer de staatsexploitatie gedurende eenigen tijd zon moeten worden voortgezet. Zelfs wanneer het gelukken mocht jaarlijks 10.000 hectaren definitjef uit te geven, zal, voor zooverre men niet mocht slageu combinatiën te vinden, die groote uitgestrektheden voorloopig in pacht nemen, de Staat moeten anvangen met zelf te exploiteeren. In het gunstigste geval zullen tien jaren noodig zijn om den zuid-ooster polder, die 95.000 hectaren groot is, geheel te plaatsen en vrij wat langer kon het aanhouden. Dat de exploitatie al dien tijd op voorloopigen voet kon worden voortgezet, is niet aannemelijk. De tijd zal aanbreken, dat behoorlijke woningen en schuren noodig zullen zijn, en de bouw daarvan zal stellig, al wordt de afdeeling $\mathrm{k} u \mathrm{n}$ sten en wetenschappen van het ministerie van Binnenlandsche zaken ook niet gehoord, in handen van staatsambtenaren vrij wat meer kosten dan wanneer zij door de landbouwers worden tot stand gebracht. Dan zullen tot behoud of vermeerdering van het productief vermogen van den grond ook allerlei maatregelen van geringere of grootere beteekenis wenschelijk worden, die verplichten zullen nieuw kapitaal in de Zuiderzee te steken. De eenige cultuur, die den Staat kan worden toevertrouwd, is de hoogst extensieve boschcultuur; zij vraagt weinig kapitaal en weinig arbeid, voornamelijk slechts geduld, dat de Staat in groote mate bezit. De natuur eischt bij haar zeer weinig bijstand. De bekwaamste houtvester kan den groei der boomen slechts weiuig bevorderen. Maar daarom mag men zich op de ervaring met boschcultuur verkregen, ook niet beroepen. Onder den titel: ein uationalökonomisches Hauptprincip der Forstwisseuschaft sohreef Roscher een keurig essai, warin het groote onderscheid tusschen boschteelt en andere cultures duidelijk wordt niteengezet en overtuigend wordt aangetoond, wat niet beter dan met zijne eigen woorden kan worden weergegeven, dat "wenn man bedenkt dass eine gute, zeitgemässe Forstwirthschaft hinter einer ebenso guten, zeitgemässen Landwirthschaft hinsichtlich der Intensität ihres Betriebes immer um einige Stufen, vielleicht Menschenalter und Jahrhunderte zurücksteht, so wird man es begreiflich finden, das für jene auch eine Menge socialer Einrichtungen noch passend, ja 
unentbehrlich sein können, welche die Landwirthschaft bereits längere oder kürzere Zeit entwachsen ist. ')

\section{XI.}

Wauneer de Minister van Waterstaat, Handel en Nijverheid aan zijne ambtgenooten mocht voorstellen aan het advies der Staatseommissie gevolg te geven, zal de minister van financiën allicht de vraag opperen of partieele indijking niet de voorkeur verdient.

Partieele indijking vordert van de schatkist eene wel niet geringe, doch in elk geval veel beperktere verbintenis dan het plan der Commissie inhoudt. De vier polders zullen, wanneer de afsluiting niet voorafgaat, vier zelfstandige werken zijn, die niet noodwendig achtereenvolgens behoeven te worden ondernomen. Zelfs wanneer men met de droogmaking niet zou aauvangen, tenzij men vertrouwde met de indijking der vier polders onafgebroken voort te zullen gaan, ook dan nog zou deze wijze van uitroering het voordeel hebben dat men, mochten de kosten tegenvallen, of bij de uitgifte der gronden bezwaren worden ondervonden, of redenen van politieken of economischen aard het ongewenscht doen zijn de inpoldering onafgebroken voort te zetten, na de voltooiing van iederen polder een rustpunt vindt, met de verkregen ondervinding kan te rade gaan of het gewenscht is onverwijld met de indijking van een volgenden polder een anvang te maken, en zoo noodig zonder overwegend bezwaar en groot renteverlies kan pauseeren. Het engagement, dat het werk in dil geval voor den Staat zou medebrengen, zou aanmerkelijk geringer zijn, een gansch ander karakter hebben, dan dat hetwelk het plan van de Zuiderzeecommissie hem oplegt. De Noord-westelijke polder, waarmede begonnen zou kunnen worden, zal 18.300 H.A. beslaan en in tien jaren voor $\mathrm{f} 28$ millioen kunnen worden tot stand gebracht. De Noord-oostelijke polder, groot 48.400 H.A. zal ongeveer $f 72$ millioen vorderen. De Zuid-oostelijke,

1) Ansichten der Volkswirthschaft aus dem geschichtlichen Standpunkte, I, pag. 297. Zie ook System der Finanzwissenschaft pag. 44.

ECuN. 1897. 
groot 98.000 H.A. zal ruim f 129 millioen eischen, en de kosten van den Zuid-westelijke worden op ruim f 50 millioen geraamd. Met een kapitaal van $f 28$ millioen zou op deze wijze een aarvang kunnen worden gemaakt, en de uitgifte der 18500 H.A., die men zou verkrijgen, zon, mocht zij in twee jaren niet slagen, zonder groot bezwaar over een langer tijdvak kunnen worden verdeeld. Men zou niet gehaast worden door het vooruitzicht, dat binnen korten tijd wederom nieuwe gronden zullen zijn ingepolderd, waarvoor ook zou moeten worden gezorgd. Men zou de uitkomsten, die de eerste inpoldering zou geven, kalm kunnen afwachten alvorens verder te gaan, en naar deze uitkomsten zou beslist kunnen worden of met eene volgende inpoldering een aanvang zal worden gemaakt, gelijk wederom de resultaten van deze kunnen leeren of op den ingeslagen weg verder kon worden voortgeschreden.

Dat de kosten der drooginaking op deze wijze hooger zouden zijn dan wanneer de afsluitdam wordt gelegd, is verre van zeker De polderdijken zullen het zeewater moeten keeren en dus zwaarder moeten zijn. De Commissie raamt de kosten zonder renteverlies op $\mathrm{f} 212700.000$ of bijna $\mathrm{f} 24$ millioen hooger dan wanneer haar plan zal worden uitgevoerd, en het is mogelijk dat, wanneer de vier polders niet achtereenvolgens worden drooggelegd, de kosten nog iets zullen stijgen. Doch het verschil in kosten is werkelijk niet van beteekenis. Wanneer het renteverlies in aanmerking wordt genomen, zijn de kosten van beide plannen vrij wel gelijk, en het gevaar dat het renteverlies de raming zal overtreffen, is, indien het plan der Commissie wordt gevolgd, onbetwistbaar veel ernstiger.

De afsluitdijk moge voor den waterstaat groote voordeelen ambieden, uit een financieel oogpunt is hij een bezwaar van gewicht. Hij maakt de droogmaking tot een onverbreekbaar geheel van buitengewonen omvang en verhoogt hiermede het risico der onderneming. Ongerekend het renteverlies en de bijkomende werken zal hij f 41 millioen kosten. De verbetering van de waterverversching en waterloozing van de aan de Zuiderzee grenzende landen en alle verdere voordeelen wettigen deze uitgaaf niet. De heer Lely verklaart zelf in de vijfde nota der Zuiderzee-Vereeniging, dat zij, buiten verband tot de droogmaking beschouwd, niet van dien aard zijn, dat daarvoor 
de visscherij der Zuiderzee kan worden opgeofferd, en de visschers zullen met f $4 \frac{1}{2}$ millioen worden schadeloosgesteld. Het is mogelijk dat de voordeelen, die moeielijk onder eijfers zijn te brengen, aldus te laag zijn geschat, en eer, naar de Commissie meent, geacht mogen worden gelijk te staan met de gekapitaliseerde rente gedurende de drooglegging voor de kosten van de afsluiting te betalen; maar in beide gevallen zijn deze kosten in hoofdzaak niet anders te beschouwen dan als voorbereidende kosten der droogmaking, die uit de opbrengst der intepolderen gronden zullen moeten worden teruggevonden en, ook teruggevonden zullen worden - zoo de verwachting dat de 190.000 hectaren achtereenvolgens in den geraamden tijd zullen worden ingedijkt en in cultuur gebracht, zich inderdaad verwezenlijkt. Met den afsluitdijk aanvaardt de Staat dus de verplichting het werk te voltooien op straffe van de daarasn besteedde kosten, of een min of meer belangrijk deel niet terugvergoed te erlangen en zelfs, zoodra de dijk zal zijn gelegd, de droogmaking aan te vangen en onafgebroken voort te zetten op poene van voor de ten behoeve van de afsluiting opgenomen gelden rente te betalen, zonder de vruchten daarvan ten volle te genieten.

Iaat het nu, naar in het verslag wordt gezegd, slechts eene quaestie van temperament zijn of men de onderneming, zooals zij door de Commissie wordt voorgesteld, aandurft, er behoort buiten eenigen twijfel groot optimisme toe, om haar niet geringe kwade kansen licht te tellen. De baten, die uit de uitgifte der gronden in de schatkist zullen terug vloeien, blijven altijd, hoe men ook rekent, bezwanrlijk met eenige nauwkeurigheid te becijferen, en het risico, dat hieruit voortspruit, wordt zeer belangrijk, wanneer meer dan 190.000 hectaren zullen moeten worden uitgegeven. Ln al wil men ook annnemen, dat de begrooting niet zal tegenvallen, onzeker blijft de duur der onderneming. Zelfs, wanneer bij het werk teleurstellingen, die zoo zelden uitblijven, niet worden ondervonden, kan de voorgenomen jaarlijksche uitgifte van tienduizend hectaren, al geschiedt zij ook op verschillende wijzen, op bezwaren stuiten, die nopen de uitgifte, wellicht ook de droogmaking over een langer tijdvak dan geraamd wordt, te verdeelen. Het gevaar is vooral groot, wanneer de uitgifte in een ongun- 
stigen tijd mocht vallen, met een dalende markt voor landbouwproducten mocht samentreffen. Blijken de koopprijzen of erfpachten, die de Staat kan bedingen, een niet gering verlies te laten, en mochten voor den nieuw ingedijkten grond ook moeielijk pachters op behoorlijke voorwaarden zijn te vinden, zoodat de Staat gedwongen wordt groote uitgestrektheden in eigen beheer te nemen, dan kon men wel eens tegen wil en dank gedwongen worden om zich voorshands te bepalen tot de voltooing van de inpoldering, waarvan de bedijking was begonnen. Zelfs wanneer het in het belnng der schatkist zou ziju, met de uitgifte, voor zooverre eenigszins doenlijk, geregeld voort te gaan, kon van agrarische zijde vroeg of laat eene beweging ontstaan, die uit vrees dat eene verdere uitgifte van gronden hare belangen mocht schaden, de landprijzen drukken en de arbeidsloonen doen stijgen, zou aandringen vooral geen haast te maken, en bij den invloed van het platteland, die, naar het voorbeeld van Duitschland en Frankrijk leert, onder een uitgebreid kiesrecht eer toeneemt dan vermindert, de Regeering zou nopen met hare inzichten rekening te houden. Ook evenementen van politieken of financieelen aard kunnen het tijdelijk ongewenscht maken meer dan het hoog noodige voor de Zuiderzee van de schatkist te vorderen. In den langen tijd, dien de droogmaking zal eischen, kunnen dus allerlei gebeurtenissen plaats grijpen, die de afwikkeling der onderneming vertragen, en elke vertraging verlengt den duur van den geenszins geringen rentelast van het in den afsluitdijk en de overige werken gestoken kapitaal.

De Commissie ziet hierin geen reden tot aarzeling. Zij geeft toe dat de baten, die de schatkist uit de opbrengst der gronden zal ontvangen, moeielijk met eenige nauwkeurigheid te ramen zijn, doch al zou de onderneming ook een te kort laten, het zal naar haar oordeel altijd ruim gedekt worden door de voordeelen der afsluiting en de indirecte baten, die de volkswelvaart van de droogmaking zal genieten.

Het is mogelijk, dat deze verwachting zal vitkomen, wanneer noch bij de uitvoering van het werk noch bij de uitgifte van de gronden teleurstellingen van beteekenis worden ondervonden. Maar voor de vele kwade kansen en den grooten omvang der onderneming biedt zij weinig marge. 
Het is geenszins uitgesloten, dat zij, afgescheiden van de zory, die zij baren kan, bij het afsluiten der rekening, ook al slaat meu de indirecte winsten hoog aan, verlies zal laten ${ }^{1}$ ). En al zal mettertijd, wanneer de doorgestane

1) Merkwaardig is dat vele, zoo niet de meeste droogmakingen voor de eerste ondernemers en hunne naaste opvolgers groote verliezen hebben medegebracht. In het meesterwerk van Mr. G. de Vries, Het Dijks- en molenbestuur in Holland's Noorder kwartier onder de grafelijke Regeering en de Republiek wordt te dien anzien menig treffende bijzonderheid gemeld. Niettegenstaande de kosten van droogmakingen van enkele Noord-Hollandsche polders gemiddeld f 800 à $f 1000$ per morgen hadden bedragen, konden vele dier gronden langen tijd geen noemenswaardigen prijs erlangen. In de Zijpe waren perceelen, dio als stuivers en rosenobles-landen bekend stonden, omdat zij voor dien prijs verkocht waren. In de Heer Hugowaard konden de hofsteden langen tijd nauwelijks in koop opbrengen, wat zij aan betimmering en beplanting hadden gekost. Ettelijke partijen waren daar omstreeks 1669 en 1677 voor f50 à f 100 het morgen verkocht, en verhaald wordt, dat men omstreeks 1684 er ernstig over gedacht heeft de Rekenkamer te verzoeken den polder weder te mogen laten onderloopen, ten einde dien voortaan als vischwater te gebruiken. In 1728 klaagde de Wijde Wormer, dat men het land aldaar niet kwijt kon worden, al wilde men ook geld toegeven. De Schermer beweerde terzelfden tijd, dat de huren nauwelijks voldoende waren om de lasten te dekken. In de Engewormer, waar de kosten van bedijking en droogmaking tot $f 1300$ het morgen gestegen waren, waren, zooals men in 1741 berekende, de landen sedert 1691 duor elkaar voor niet hooger dan $\mathrm{f} 42.75$ per morgen verkocht. Het verlaten en spasteken van gronden was dientengevolge in menigen drooggemaakten plas geen zeldzaamheid. Integendeel, het kwam zoo veelvuldig voor, dat de Staten den $6^{\text {den }}$ Maart 1751 aan Schouten en gerechten gelasten bij de overdracht van land, die te hunmen overstaan plaats vond, borgtocht te vorderen voor de betaling der lasten gedurende de eerste zes jaren, en bij gebreke van dien tot de overdracht niet mede te werken. Vele gronden werden in die dagen aan het Domein geabandonneerd.

Dat een dergelijke toestand zich ook in de Zuiderzee zou kunnen voordoen, acht ik onaannemelijk. De pachtwaarde is in onzen tijd veel hooger dan in de vorige eenw en zal niet licht weder tot het oude peil dalen. 
moeielijkheden zijn vergeten, en de voor de onderueming aangegane schuld geheel of gedeeltelijk zal zijn geamortiseerd, het nageslacht, dat de kwade dagen niet medemaakte, dankbaar gestemd zijn door het waardevol bezit der drooggemaakte Zuiderzee en de welvaart, die zij verspreidt; de Regeering, die het werk zal ondernemen, is niet verantwoord, wanneer zij uitsluitend of hoofdzakelijk het oog vestigt op een wellicht ver verwijderde toekomst, waaromtrent van te voren altijd kwalijk te oordeelen valt, en niet allereerst zich rekenschap geeft van de gevolgen, die de onderneming voor de tegenwoordige belastingschuldigen en hunne naaste opvolgers kon hebben; wanneer zij zich niet de vraag stelde of de taak, die zij zou aanvaarden, gedurende de uitroering niet betrekkelijk te groote offers van de natie kon vergen, wegens haar omvang te eeniger tijd ongelegen kon komen, en bezwaarlijk in den geraamden tijd naar behooren kon worden ten einde gebracht.

Dat in dien stand van zaken de vruchtbare velden der Zuiderzee nog lang onder het water bedolven zullen blijven, is geene gewaagde onderstelling. Aanvankelijk schijnen de feiten haar zelfs te bevestigen. De Regeering heeft nog van geene geneigdheid doen blijken om het plan, dat de Commissie haar voorstelt, te aanvaarden of zelfs ernstig te overwegen. De Minister van Waterstaat, Handel en Nijverlıeid heeft alleen twijfel uitgesproken of de Natie het werk verlangt. En onder de maatregelen, die van den Staat worden gevraagd, is door geen der politieke partijen, hoe breed zij ook met het oog op de naderende verkiezingen hare eischen formuleerden, aan de droogmaking der Zuiderzee eene plaats ingeruimd. Het uitgewerkte hervormingsprogramma der Liberale Unie, dat naar de eigen getuigenis van het Bestuur eene lange reeks van wenschen voor vele jaren bevat, zinspeelt zelfs niet op haar bij de omschrijving der maatregelen, die ter ontwikkeling van landbouw, veeteelt, handel en nijverheid noodig worden geacht. En waar de Zuiderzee-Vereeniging en haar schildknaap de Nationale Zuiderzeebond voor eene droogmaking na voorafgegane afsluiting ijveren, zal partieele indijking vooreerst niet nader worden overwogen en weinig voorstanders vinden.

De droogmaking der Zuiderzee is dus een vraagstuk, waarvan de oplossing zich vooreest niet laat verwachten, tenzij de 
Regeeriug eu Volksvertegenwoordiging geen bezwaar zouden hebben als eene eerste bijdrage $f 50$ à 60 millioen voor de afsluiting en bijkomende werken te bestemmeu, ook al zou de indijking der polders slechts langzaam, des noods zelfs met groote tusschenpoozen volgen; ò wel zich allengs de overtuiging mocht vestigen, dat ook door den grooten waterplas geleidelijk partieel te veroveren een grootsch en voor het Vaderland nuttig werk zou worden verricht.

Amsterdam, November 1896.

F. S. VAN Nierop. 